\title{
A dual-component carrier with both non-enzymatic and enzymatic antioxidant activity towards ROS depletion
}

York-Durán, María José; Gallardo, Maria Godoy; Jansman, Michelle Maria Theresia; Hosta-Rigau, Leticia

Published in:

Biomaterials Science

Link to article, DOI:

10.1039/c9bm00913b

Publication date:

2019

Document Version

Peer reviewed version

Link back to DTU Orbit

Citation (APA):

York-Durán, M. J., Gallardo, M. G., Jansman, M. M. T., \& Hosta-Rigau, L. (2019). A dual-component carrier with both non-enzymatic and enzymatic antioxidant activity towards ROS depletion. Biomaterials Science, 7, 48134826. https://doi.org/10.1039/c9bm00913b

\section{General rights}

Copyright and moral rights for the publications made accessible in the public portal are retained by the authors and/or other copyright owners and it is a condition of accessing publications that users recognise and abide by the legal requirements associated with these rights.

- Users may download and print one copy of any publication from the public portal for the purpose of private study or research.

- You may not further distribute the material or use it for any profit-making activity or commercial gain

- You may freely distribute the URL identifying the publication in the public portal 


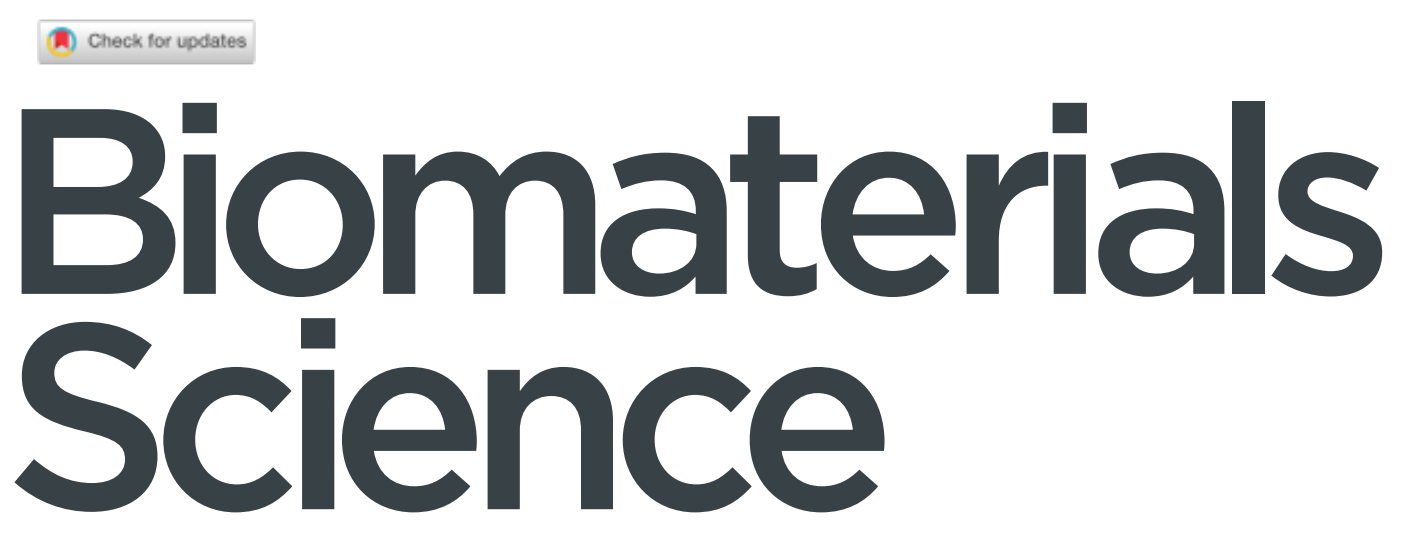

\section{Accepted Manuscript}

This article can be cited before page numbers have been issued, to do this please use: M. J. York-Duran,

M. Godoy-Gallardo, M. M. T. Jansman and L. Hosta-Rigau, Biomater. Sci., 2019, DOI:

\section{Biomaterials Science}

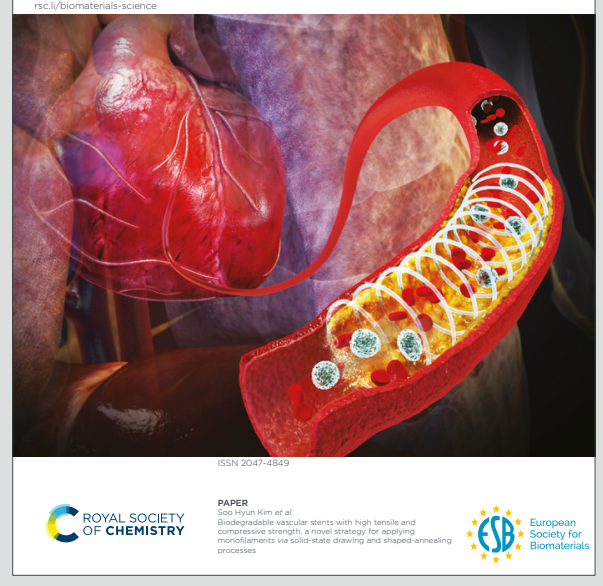

This is an Accepted Manuscript, which has been through the Royal Society of Chemistry peer review process and has been accepted for publication.

Accepted Manuscripts are published online shortly after acceptance, before technical editing, formatting and proof reading. Using this free service, authors can make their results available to the community, in citable form, before we publish the edited article. We will replace this Accepted Manuscript with the edited and formatted Advance Article as soon as it is available.

You can find more information about Accepted Manuscripts in the Information for Authors.

Please note that technical editing may introduce minor changes to the text and/or graphics, which may alter content. The journal's standard Terms \& Conditions and the Ethical guidelines still apply. In no event shall the Royal Society of Chemistry be held responsible for any errors or omissions in this Accepted Manuscript or any consequences arising from the use of any information it contains. 


\title{
ARTICLE
}

\section{Dual-component Carrier with both Non-enzymatic and Enzymatic Antioxidant Activity towards ROS Depletion}

Received 00th January 20xx, Accepted 00th January 20xx DOI: $10.1039 / x 0 x \times 00000 x$

\author{
Maria Jose York-Duran, Maria Godoy-Gallardo, Michelle Maria Theresia Jansman and Leticia Hosta- \\ Rigau* $^{*}$
}

\begin{abstract}
While ROS display crucial functions in many physiological processes, elevated ROS levels are also related to the initiation and progression of many severe diseases such as cancer, cardiovascular conditions or neurologic disorders. Research approaches to diminish ROS levels during disease progression are currently focusing on the therapeutic administration of antioxidant enzymes. However, enzyme administration suffers from several limitations including their fast elimination from blood upon administration, thus making crucial the development of enzyme encapsulating platforms. We have recently reported a multicompartment architecture constituted by two inherently different types of materials, i.e., polymeric microgels and liposomes. Poly( $N$-isopropylacrylamide-co-acrylic acid) microgels decorated with liposomes and subsequently coated by a protective poly(dopamine) shell (PDA) combine the benefits of both systems while minimizing some of their drawbacks. Herein, we exploit this dual-component platform as a microreactor for ROS depletion. We combine the intrinsic PDA's antioxidant properties with the encapsulation of the catalase enzyme within the liposomal compartments. The surface of the carrier is further functionalised with a poly(ethylene glycol) layer and the low fouling properties are demonstrated in terms of reduction of protein adsorption and cellular uptake. The potential of the carrier as an antioxidant microreactor is shown by its ability to deplete superoxide radicals and hydrogen peroxide, which can also take place in the presence of two relevant cell lines.
\end{abstract}

\section{Introduction}

Reactive oxygen species (ROS) are highly reactive molecules with demonstrated crucial roles in both human physiological and pathophysiological processes. ${ }^{1}$ ROS can be neutral molecules (e.g., hydrogen peroxide $\left(\mathrm{H}_{2} \mathrm{O}_{2}\right)$ ), ions (e.g., superoxide anion $\left(\mathrm{O}_{2}{ }^{-}\right)$) or radicals (e.g., hydroxyl radicals $\left.\left({ }^{\circ} \mathrm{OH}\right)\right)$. Due to their high reactivity, ROS rapidly react with other species in order to stabilize their structure. Typically, ROS are generated when molecular oxygen $\left(\mathrm{O}_{2}\right)$, upon reaction with electrons, is transformed into $\mathrm{O}_{2}{ }^{\circ-}$ which then can be converted into $\mathrm{H}_{2} \mathrm{O}_{2}$ either by self-dismutation or by means of the superoxide dismutase (SOD) enzyme. ${ }^{2}$

In our bodies, ROS are continuously generated as by-products of the oxygen metabolism and have crucial roles in critical physiological processes. While, at the cellular level, ROS regulate growth, apoptosis and other cell signalling cascades; at the systems level they contribute to complex functions such as the regulation of blood pressure, cognitive function or the generation of the inflammatory response. ${ }^{1}$ Furthermore, ROS also play vital roles in the immune system by directly killing pathogens. ${ }^{1}$

Department of Health Technology, Centre for Nanomedicine and Theranostics, DTU Health Tech, Technical University of Denmark, Building 423, 2800, Lyngby, Denmark.

Electronic Supplementary Information (ESI) available: [details of any supplementary information available should be included here]. See DOI: 10.1039/x0xx00000x
Despite their important actions, elevated ROS levels are closely linked with initiation and progression of a variety of diseases including cancer, neurologic disorders, inflammatory diseases and virtually all cardiovascular conditions. ${ }^{3-5}$ This is due to the fact that these highly active species can lead to lipid peroxidation, protein denaturation and DNA damage, which frequently translates into irreversible tissue and organ damage. ${ }^{2}$ In our organism, many antioxidant enzymes work together to scavenge excessive ROS and maintain the redox balance. ${ }^{6}$ As an example, the SOD enzyme catalyses the dismutation of harmful $\mathrm{O}_{2}{ }^{-}$into $\mathrm{O}_{2}$ and $\mathrm{H}_{2} \mathrm{O}_{2}$. The generated $\mathrm{H}_{2} \mathrm{O}_{2}$ can then be decomposed into nontoxic $\mathrm{H}_{2} \mathrm{O}$ and $\mathrm{O}_{2}$ by means of other antioxidant enzymes such as catalase (CAT) or glutathione peroxidase. ${ }^{6}$

Since, during disease progression, these antioxidant enzymes are overwhelmed by dramatically elevated ROS, research efforts have focused on the therapeutic administration of SOD and CAT as potential antioxidant drugs. ${ }^{7}$ However, a major hurdle in the translation of enzyme-based therapies into the clinical domain lies in their in adequate delivery since, following administration, enzymes are eliminated from blood within minutes. ${ }^{7,8}$ Thus, in an attempt to make use of their excellent ROS removal capacities, approaches to enhance their bioavailability include the conjugation of CAT and SOD to polyethylene glycol (PEG) or PEG-based pluronics. ${ }^{9}$ However, covalent modifications of enzymes and proteins results in modification of their secondary structure and the associated altered catalytic activity. As such, recent approaches are 
focusing on encapsulation platforms where the enzymes are protected from coming into direct contact with degrading proteases in the bloodstream or in the intracellular environment. Therefore, enzymes are then able to conduct multiple cycles of biocatalytic conversions, acting as micro/nanoreactors. Reports to date include the encapsulation of antioxidant enzymes within several carriers including liposomes, ${ }^{10}$ polymersomes, ${ }^{11}$ polymer capsules $^{12}$ or mesoporous silica particles. ${ }^{13}$ While these encapsulation platforms have successfully demonstrated the ability to sustain enzymatic reactions, even within the complex intracellular environment, ${ }^{11-13}$ it is worth noticing that such architectures are typically fabricated by a single constituent material (i.e., lipids, polymers or silica). However, hybrid architectures composed of two different types of materials have emerged as an interesting alternative. By combining two inherently different building blocks, dual-component carriers can exploit the advantages of both systems while minimizing some of their drawbacks. ${ }^{14-17}$ As an example, the hybrid system consisting of liposomes entrapped within a polymeric carrier shell has emerged as one of the most advanced and thoroughly studied hybrid architectures reported to date. Such a system has proven to be particularly well suited for enzyme delivery or biocatalysis for different therapeutic applications. ${ }^{16}$ While liposomes, by means of their resemblance to cell membranes, are optimal carriers for fragile enzymes protecting them from denaturation; the outer polymeric shell supplies the required structural integrity. Liposomes display in vivo instability and lack of control over degradation, which can be surmounted by embedding them within a polymeric matrix. ${ }^{18,19}$ Additionally, the polymeric carrier is semipermeable, which makes it possible for substrates and products to diffuse in and out enabling for continuous catalytic conversion. Such an architecture has demonstrated preserved enzymatic activity in the presence of cells $s^{20,21}$ or within the complex intracellular environment. ${ }^{22-24}$ Furthermore, recent reports have moved away from proof-ofconcept ideas towards therapeutic applications such as e.g., bone tissue engineering, ${ }^{25}$ phenylketonuria ${ }^{26}$ or melanoma treatment. $^{27}$

We have recently reported a variation of this hybrid platform where poly( $N$-isopropylacrylamide-co-acrylic acid) (p(NIPAAMco-AAc)) microgels (MGs) were decorated with liposomes and subsequently coated by a protective poly(dopamine) shell (PDA). ${ }^{28}$ Such a system was evaluated in the context of codelivery for therapeutic compounds. While p(NIPAM-co-AAc) MGs exhibit a fast release profile due to their large pore sizes, ${ }^{28}$ liposomes were chosen as the second type of compartments to attain a slower release profile. Next, PDA, the self-assembly product of dopamine (DA) which easily attaches homogeneously onto almost all kinds of substrates with controllable film thickness, was used as a coating to enhance liposomes stability. ${ }^{28,29}$ Interestingly, PDA as the most common synthetic melanin analogue, possesses excellent antioxidant ability. ${ }^{30}$

Herein with the aim to advance our dual-component platform, we explore its potential as a microreactor for ROS depletion by making use of PDA's antioxidant properties. Additionally,

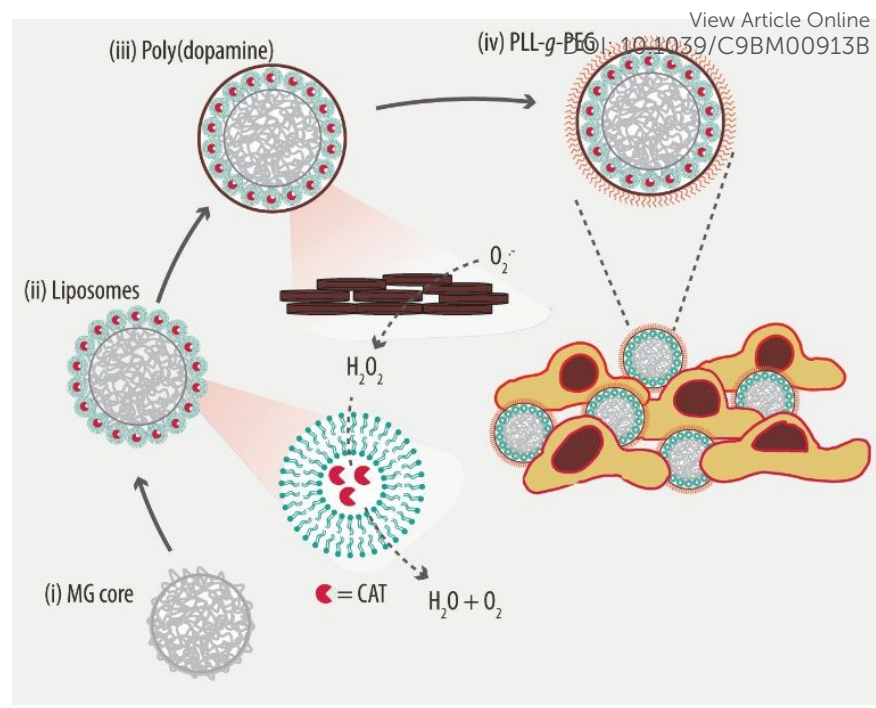

Scheme 1. Schematic illustration of the assembly process. A microgel (MG) core (i) is decorated with a liposome layer loaded with the catalase (CAT) enzyme (ii) Next, a polydopamine coating is deposited (iii) and further functionalised with poly(L-lysine)-graft-poly(ethylene glycol) (PLL-g-PEG) (iv). The superoxide radical $\left(\mathrm{O}_{2}{ }^{-}\right)$is converted into hydrogen peroxide $\left(\mathrm{H}_{2} \mathrm{O}_{2}\right)$ by the polydopamine coating. Next, $\mathrm{H}_{2} \mathrm{O}_{2}$ interacts with the catalase (CAT) enzyme encapsulated within the liposomal compartments of the carrier to be converted into non-toxic $\mathrm{H}_{2} \mathrm{O}$ and $\mathrm{O}_{2}$. The antioxidant reactions can take place in the presence of relevant cell lines. inspired by our body, where antioxidant biomolecules work together with enzymes to provide protection against oxidative damage; ${ }^{31}$ we incorporate the antioxidant CAT enzyme within the liposomal subcompartments (Scheme 1). To achieve longcirculation in the blood stream, we further functionalise the PDA shell with a PEG-based co-polymer. Finally, the antioxidant activity of the carrier towards $\mathrm{O}_{2}{ }^{-}$and $\mathrm{H}_{2} \mathrm{O}_{2}$ is assessed in a test tube and in the presence of relevant cell lines.

\section{Experimental Methods}

\subsection{Materials}

$\mathrm{N}$-isopropylacrylamide (NIPAM), acrylic acid (AAC), $N, N^{\prime}-$ methylenebiscarylamide (BA), ammonium persulfate (APS), tris(hydroxymehtyl)aminomethane (Tris), sodium chloride ( $\mathrm{NaCl})$, 4-(2-hydroxyethyl) piperazine-1-ethane-sulfonic acid (Hepes), dopamine hydrochloride (DA), fluorescein isothiocyanate (FITC), FITC-labelled immunoglobulin G (IgGFITC), bovine serum albumin (BSA), phosphate buffered saline (PBS), chloroform anhydrous (> 99\%), Triton X-100, Dulbecco's Modified Eagle's Medium-high glucose (DMEM D5796), sodium pyruvate, penicillin/streptomycin, fetal bovine serum (FBS), trypsin, PrestoBlue ${ }^{\circledR}$ cell viability reagent kit, dimethyl sulfoxide (DMSO), sodium bicarbonate $\left(\mathrm{NaHCO}_{3}\right)$, poly-L-lysine (PLL) (Mw 15 000-30000 Da), catalase (CAT) from bovine liver (EC1.11.1.6, $\left.10000 \mathrm{U} \mathrm{mg}{ }^{-1}\right)$, potassium dioxide $\left(\mathrm{KO}_{2}\right)$, horseradish peroxidase (HRP) (EC1.11.1., $250 \mathrm{U} \mathrm{mg}^{-1}$ ), cytochrome $\mathrm{C}$ from equine heart, ethylenediaminetetraacetic acid solution (EDTA), xanthine, xanthine oxidase (XO) from bovine milk were purchased from Merk (Kenilworth, New Jersey, USA). Human umbilical vein endothelial cells (HUVEC, neonatal, pooled) and 
RAW 264.7 cell line murine macrophage from blood were also purchased from Merk (Kenilworth, New Jersey, USA). Amplex Red Reagent and micro-bicinchoninic acid (BCA) assay kit were purchased from ThermoFisher Scientific (Waltham, MA, USA). 1,2-Dimyristoyl-sn-glycero-3-phosphocholine (DMPC), 1,2dipalmitoyl-sn-glycero-3-phosphocholine (DPPC), 1,2-stearoyl3-trimethylammonium-propane (chloride salt) (DSTAP) and 1myristoyl-2-[12-[(7-nitro-2-1,3-benzoxadiazol-4

yl)amino]dodecanoyl]-sn-glycero-3-phosphocholine (NBD-PC) were obtained from Avanti Polar Lipids (Alabaster, AL, USA). Endothelial Growth Medium-2 Bullet kit (EGM-2) was purchased from Lonza (Basel, Switzerland). The EGM-2 is composed of Endothelial Basal Medium (EBM), human epidermal growth factor (hEGF), vascular endothelial growth factor (VEGF), R3-insulin-like growth factor-1 (R3-IGF-1), ascorbic acid, hydrocortisone, FBS, human fibroblast growth factor-beta (hFGF- $\beta$ ), heparin and gentamicin/amphotericin-B (GA). $\alpha$-Methoxy- $\omega$-carboxylic acid succinimidyl ester poly(ethylene glycol) (Me-PEG-NHS, Mw PEG = $2000 \mathrm{Da}$ ) was purchased from Iris Biotech $\mathrm{GmbH}$ (Marktredwitz, Germany).

Tris 1 buffer is composed of $10 \mathrm{mM}$ Tris $(\mathrm{pH} \mathrm{8.5);} \mathrm{Tris} 2$ is composed of $10 \mathrm{mM}$ Tris and $150 \mathrm{mM} \mathrm{NaCl}(\mathrm{pH} 7.4)$; Hepes is composed of $10 \mathrm{mM}$ Hepes and $150 \mathrm{mM} \mathrm{NaCl}$ (pH 7.4). All buffers were prepared with ultrapure water (Milli- $Q$, gradient $A$ 10 system, TOC $<4 \mathrm{ppb}$, resistance $18 \mathrm{MV} \mathrm{cm}$, EMD Millipore, USA).

BSA was fluorescently labelled with FITC as previously reported. ${ }^{32}$ Briefly, a FITC solution ( $3.7 \mathrm{mg}$ FITC in $300 \mu \mathrm{L}$ DMSO) was added dropwise to a BSA solution (30 mg BSA in $6 \mathrm{~mL} 0.05$ $\mathrm{M} \mathrm{NaHCO}_{3} \mathrm{pH} 10$ buffer). After incubation overnight at room temperature, the unreacted FITC was removed by two days dialysis against Milli- $Q$ water and the as-prepared BSA-FITC was freeze-dried.

\subsection{MGs synthesis and characterization}

p(NIPAAM-co-AAC)-based MGs were synthesized following our previously reported procedure. ${ }^{28}$ Briefly, recrystallized NIPAM (3.97 mmol), AAc (0.69 mmol) and BA (0.097 mmol) were dissolved in Milli- $Q$ water $(30 \mathrm{~mL})$ and filtered into a $100 \mathrm{~mL}$ three-neck round-bottom flask equipped with an argon inlet and outlet (a $0.22 \mu \mathrm{m}$ cellulose acetate filter was employed). The reaction mixture was heated to $80{ }^{\circ} \mathrm{C}$ while stirring and purged for $1 \mathrm{~h}$ with an argon flow. The polymerization was then initiated by addition of APS $(0.024 \mathrm{mmol})$ and allowed to proceed overnight. The resulting product was filtered through glass wool and purified by several washes with Milli- $Q$ water at $6{ }^{\circ} \mathrm{C}$ (17 $100 \mathrm{~g}, 45 \mathrm{~min}$ ) employing a Thermo Scientific SL16R high-speed centrifuge. The concentration of the suspension was determined by weighting out several freeze-dried aliquots. The

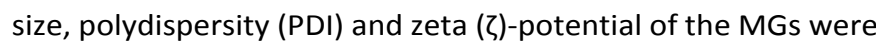
determined by dynamic light scattering (DLS) using a ZetaPALS $\zeta$-potential analyzer (Brookhaven Instruments Corporation, Holtsville, NY, USA).

\subsection{Liposomes assembly and characterization}

To fabricate unilamellar empty liposomes (L), DMPC (1.63 mg), DPPC (0.63 mg) and DSTAP $(0.25 \mathrm{mg})$ were dissolved in chloroform followed by the formation of a lipid film using a nitrogen flow. Next, the film was exposed to vacuum for 1 i band rehydrated in Tris 2 buffer $(1 \mathrm{~mL})$. The Oresenteig solution was extruded 11 times at $45^{\circ} \mathrm{C}$ through nucleopore polycarbonate filters of $100 \mathrm{~nm}$ (drain disc $10 \mathrm{~mm} \mathrm{PE}$, Whatman, Maidstone, UK). To prepare fluorescently labelled liposomes $\left(L^{F}\right) 2 w t \%$ of NBD-PC was added to the lipid mixture prior formation of the lipid film. The size and PDI of the liposomes $\left(L\right.$ and $\left.L^{F}\right)$ was determined by $D L S$ and $\zeta$-potential measurements. Only $L$ and $L^{F}$ with a PDI below 0.14 were considered for the following experiments. The fluorescence intensity of $L^{F}$ was measured using a multimode plate reader (Victor ${ }^{3}-1420$ Multilabel Counter, PerkingElmer, Waltham, MA, USA) at excitation/emission wavelengths of $430 / 535 \mathrm{~nm}$. The $\mathrm{L}^{\mathrm{F}}$ samples were adjusted to the same fluorescence intensity value by conducting serial dilutions.

\subsection{Fabrication of the dual-component carrier}

2.4.1. Optimization of Ls deposition. A suspension of MGs (479 $\mu \mathrm{g})$ was washed in Tris 1 buffer $(2 \times, 15 \mathrm{~min}, 12247$ gusing a bench-top centrifuge (MiniSpin, Eppendorf, AG; Germany) which was used for all the following experiments. Next, the MGs were incubated with increasing amounts of LF in a tube rotator (1.5 $\mathrm{h}$, room temperature) keeping the total volume constant. The MG/LF suspension was washed in Tris 1 buffer $(2 \times, 6 \mathrm{~min}$, $6720 \mathrm{~g}$ ) and re-suspended in Tris 1 . The LF-coated MGs were monitored by flow cytometry using a BD Accuri C6 flow cytometer (BD Biosciences, Sparks, MD, USA) equipped with a $488 \mathrm{~nm}$ laser. An emission detection of $530 \mathrm{~nm}$ was employed and at least 20000 events were recorded in at least two independent experiments.

2.4.2. PDA prime-coating. Carriers entrapping empty $L(M G / L / P D A)$ or fluorescently labelled $L^{F}$ (MG/LF/PDA) were fabricated. To do so, a MGs suspension $(958 \mu \mathrm{g})$ was washed in Tris 1 buffer $(1 \times, 14 \mathrm{~min}$, $4855 \mathrm{~g}$ ) and incubated with liposomes ( $\mathrm{L}$ or $\mathrm{L}^{\mathrm{F}}, 0.25 \mathrm{mg}$ lipids) for 1.5 $\mathrm{h}$ in a tube rotator. To minimize sample loss, the washing steps prior PDA deposition were performed in amicon ultra centrifugal filters (100 kDa). Next, the liposome-coated MGs was upconcentrated to a volume of $100 \mu \mathrm{L}$ (14 min, $4855 \mathrm{~g}$ ) followed by incubation with a DA solution ( $1 \mathrm{mg} \mathrm{mL}^{-1} \mathrm{DA}$ in Tris 1 buffer). The unreacted DA and the PDA excess were removed by washing cycles in Tris 2 buffer $(2 \times, 7$ $\min , 6720 \mathrm{~g})$.

2.4.3. Differential interference contrast (DIC) and fluorescence microscopy. The DIC and fluorescence intensity images of the dualcomponent carriers were taken with an Olympus Inverted IX83 microscope equipped with a $60 \times$ oil-immersion objective.

2.4.4. Scanning electron microscopy (SEM). The different samples (MG, MG/L and MG/L/PDA) were coated with gold ( $0.9 \mathrm{~nm}$ thickness) using a Q150T ES Turbo-Pumped Sputter Coater (Quorum Technologies, UK). The images were taken employing a FEI Quanta 200 ESEM FEG scanning electron microscope (FEI Company, USA) at an accelerating voltage of $5 \mathrm{kV}$ and at a working distance of $22.9 \mathrm{~nm}$.

2.4.5. Fourier-transform infrared (FTIR) spectroscopy. FTIR analysis was conducted employing a Perkin Elmer Spectrum 100 FT-IR spectrometer (Perkin Elmer Inc., Wellesley, MA) equipped with a universal ATR accessory. The different spectra were collected within 
the wavelength range of 2000 to $750 \mathrm{~cm}^{-1}$, with a resolution of $1 \mathrm{~cm}^{-1}$. Four scans per sample were conducted.

\subsection{Surface functionalisation}

2.5.1. PEGylation. PLL-graft-PEG (PLL-g-PEG) at three different PEG-grafting ratios ( $G R=1.6,2.5$ and 3.2, respectively) were synthetized as previously reported. ${ }^{33}$ Briefly, Me-PEG-NHS (0.072, 0.029 or $0.038 \mathrm{mmol}$ for a GR of $1.6,2.5$ or 3.2, respectively) was dissolved in cold Hepes buffer $(4 \mathrm{~mL})$ and added to a solution of PLL ( $30 \mathrm{mg}$ in $0.5 \mathrm{~mL}$ cold Hepes buffer). The resulting solution was incubated for $4 \mathrm{~h}$ at $4{ }^{\circ} \mathrm{C}$ under constant shaking followed by two day dialysis in Milli- $Q$. Following lyophilisation, ${ }^{1} \mathrm{H}$ NMR analysis was used to assess the GR. ${ }^{1} \mathrm{H}$ NMR ( $\left.\mathrm{D}_{2} \mathrm{O}, \mathrm{ppm}\right)$ spectrum: 1.41, 1.65, $\left.1.72\left(-\mathrm{CH}_{2}\right)^{-}\right) ; 2.95$ (-CH $\mathrm{CH}_{2}-\mathrm{N}-$ ); 3.34 (PEG); 4.28 (-N-CHR-COO-).

PEGylated dual-component carriers (MG/L/PDA/PEG) were fabricated by incubating MG/L/PDA (958 $\mu \mathrm{g}$ in $200 \mu \mathrm{L}$ Tris 1 ) with a PLL-g-PEG solution ( $0.4 \mathrm{mg}$ in $200 \mu \mathrm{L}$ of Tris 1 ) for $1 \mathrm{~h}$ in a tube rotator. Next, the PLL- $g$-PEG excess was removed by washing cycles in Tris $2(2 \times, 7 \mathrm{~min}, 6720 \mathrm{~g})$.

2.5.2. $\zeta$-potential measurements. The assembly of the dualcomponent carrier was monitored $\zeta$-potential measurements using a Zetasizer nanoseries nano-ZS (Malvern Panalytical, UK). At least two independent experiments were carried out.

2.5.3. Protein adsorption. A suspension containing either $\mathrm{MG} / \mathrm{L} / \mathrm{PDA}$ or MG/L/PDA/PEG (0.47 mg in $200 \mu \mathrm{L}$ PBS) was incubated with either BSA-FITC or IgG-FITC at a 0.075 or $0.5 \mathrm{mg}$ $\mathrm{mL}^{-1}$ final concentration. The suspensions were incubated for 4 $\mathrm{h}$ at $37^{\circ} \mathrm{C}$ followed by washes in PBS $(3 \times, 5 \mathrm{~min}, 4855 \mathrm{~g})$ to remove unbound proteins. The fluorescence intensity signal of the carriers was monitored by flow cytometry employing a 488 $\mathrm{nm}$ laser and an emission detection wavelength of $530 \mathrm{~nm}$. At least 20000 events were analyzed in three independent experiments. The data was analyzed using one-way ANOVA with a confidence level of $95 \%(\alpha=0.05)$ followed by a Tukey's multiple comparison posthoc test $\left({ }^{*} p \leq 0.05 ;{ }^{* *} p \leq 0.01 ; * * * \leq\right.$ $0.001 ; * * * * \leq 0.0001)$ in a GraphPad Prism 7 software.

2.5.4. Cell association/uptake. The mouse macrophage RAW 264.7 cell line was cultured in DMEM supplemented with $2 \%$ (v/v) Hepes, $1 \%$ sodium pyruvate, $10 \%$ (v/v) FBS and $1 \%(v / v)$ penicillin/streptomycin $\left(10000 \mathrm{U} \mathrm{mL}^{-1}\right.$ and $10 \mu \mathrm{g} \mathrm{mL}$, respectively) at $37{ }^{\circ} \mathrm{C}$ in a humidified incubator with $5 \% \mathrm{CO}_{2}$ level. The endothelial HUVEC cell line was cultured in EBM-2 supplemented with $0.1 \%(\mathrm{v} / \mathrm{v}) \mathrm{hEGF}, 0.1 \%(\mathrm{v} / \mathrm{v})$ VEGF, $0.1 \%(\mathrm{v} / \mathrm{v})$ R3-IGF-1, 0.1\% (v/v) ascorbic acid, 0.04\% (v/v) hydrocortisone, $0.4 \%(v / v)$ hFGF- $\beta, 0.1 \%(v / v)$ heparin, $2 \%(v / v)$ FBS and $0.1 \%$ $(v / v)$ GA. The cell media was renewed every 2-3 days and only passages between three and nine (for RAW 264.7 cells) and between one and five (for HUVEC cells) were used. The cells were allowed to grow up to $\sim 80 \%$ confluence before being detached from the culture flask either by using a cell scrapper (for RAW 264.7) or trypsin ( $3 \mathrm{~mL}, 0.5 \mathrm{mg} \mathrm{mL}^{-1}$, for HUVEC cells). When employing trypsin, after the $4-5$ min incubation time, the cells were washed by centrifugation $(1 \times, 5 \mathrm{~min}, 188 \mathrm{~g})$ and resuspended in fresh cell culture media.

30000 cells (RAW 264.7) and 15000 cells (HUVEC) were seeded in each well of a 96-well plate and allowed to attach for $24 \mathrm{~h}$ prior incubation with fluorescently labelled MG/LF/PDA

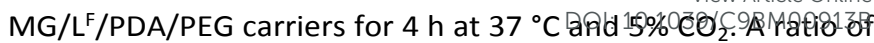
$3.7 \mathrm{ng}$ of carriers per cell was used. The cells were then washed in PBS $(2 \times)$ and detached from the wells employing trypsin $(60$ $\mu \mathrm{L}$ per well). The cell association/uptake of the carriers was evaluated by flow cytometry. The cell mean fluorescent intensity and the cellular uptake efficiency (determined as the percentage of cells with a mean fluorescence intensity higher than the auto fluorescence level of the cells) was assessed. Cells without carrier exposure were used as controls. At least 2000 events were analyzed in each experiment and at least three independent experiments were conducted. The data was analyzed using one-way ANOVA with a confidence level of $95 \%$ $(\alpha=0.05)$ using Tukey's multiple comparison posthoc test ( $*$ $0.05 ; * * \mathrm{p} \leq 0.01 ; * * * \mathrm{p} \leq 0.001 ; * * * * \mathrm{p} \leq 0.0001)$ in a GraphPad Prism 7 software.

2.5.5. Cell viability after cell association/uptake. Following incubation, the cells were washed $2 \times$ in PBS and incubated for $1 \mathrm{~h}$ at $37{ }^{\circ} \mathrm{C}$ and $5 \% \mathrm{CO}_{2}$ with cell media containing $10 \mu \mathrm{L}$ of PrestoBlue reagent. Then, $100 \mu \mathrm{L}$ of solution from each well were transferred to a different 96-well plate and the fluorescence intensity of the reduced resazurin product was measured at excitation/emission wavelengths of 535/615 nm employing a multimode plate reader (TECAN Spark, TECAN, Switzerland). Cells only were used as the positive control, and media only was used as the negative control. The percentage of cell viability was calculated as follows: $\%$ cell viability = (experimental value - negative control value)/(positive control value - negative control value). Each condition was evaluated in triplicate in three independent experiments.

\subsection{Functional performance}

2.6.1. Non-enzymatic antioxidant activity. The cytochrome $C$ assay was employed with modifications of a previously described protocol. ${ }^{34}$ In particular, a reaction mixture consisting of $1 \times 10^{-4} \mathrm{M}$ EDTA, $1 \times 10^{-5} \mathrm{M}$ cytochrome $\mathrm{C}, 5 \times 10^{-5} \mathrm{M}$ xanthine and $11.6 \mathrm{U} \mathrm{L}^{-1} \mathrm{XO}$ in Tris $2(500 \mu \mathrm{L})$ containing $800 \mu \mathrm{g}$ of either MG/L/PDA or MG/L/PDA/PEG, was incubated for up to $2 \mathrm{~h}$ at 37 ${ }^{\circ} \mathrm{C}$ under continuous shaking. Next, the samples were spun down $(7 \mathrm{~min}, 4855 \mathrm{~g})$, the supernatants $(200 \mu \mathrm{L}$ ) collected and the reduced cytochrome $C$ was monitored at $550 \mathrm{~nm}$ employing a multimode plate reader (TECAN Spark, TECAN, Switzerland).

For repeated enzymatic conversion, $800 \mu \mathrm{g}$ of either MG/L/PDA or MG/L/PDA/PEG carriers were suspended in the aforementioned reaction mixture and incubated for $30 \mathrm{~min}$ at $37{ }^{\circ} \mathrm{C}$ under continuous stirring. After the incubation time, the samples were spun down ( $7 \mathrm{~min}, 4855 \mathrm{~g}$ ), the supernatants collected and measured in the plate reader. The samples were then washed in Tris $2(1 \times, 7 \mathrm{~min}, 4855 \mathrm{~g})$ and fresh reaction mixture was added to the samples. The process was repeated for five subsequent rounds.

2.6.2. CAT encapsulation. CAT-loaded liposomes $\left(L_{\text {CAT }}\right)$ were assembled by re-hydrating the lipid film with different CAT amounts in Tris 2 buffer $(1 \mathrm{~mL})$. Following vortexing and incubation in a water bath at $45{ }^{\circ} \mathrm{C}$ for $20 \mathrm{~min}, \mathrm{~L}_{\mathrm{CAT}}$ were extruded through nucleopore polycarbonate filters of 800,400 , 200 and $100 \mathrm{~nm}$ for 11 times at $45{ }^{\circ} \mathrm{C}$. The non-encapsulated 
CAT was removed by size exclusion chromatography using a sepharose CL-4B column. Only fractions 5 to 15 were collected (see Figure S1, Supporting Information) and the $\mathrm{L}_{\mathrm{CAT}}$ solution was up-concentrated employing amicon ultra filters (100 kDa) and spinning them down (30 $\mathrm{min}, 2500 \mathrm{~g}$ ) employing a Thermo Scientific SL 16R high speed centrifuge.

The CAT entrapped or associated within $L_{C A T}$ was evaluated by incubating them in a solution of Triton X (1\% Triton X-100 in 200 $\mu \mathrm{L}$ of Tris 2 buffer) for $30 \mathrm{~min}$ followed by a micro BCA assay. The encapsulation efficiency (EE) was assessed as described in the Supporting Information. The size and PDI of $\mathrm{L}_{\mathrm{CAT}}$ was determined by DLS and ל-potential measurements.

2.6.3. CAT-loaded carriers. MGs $(1916 \mu \mathrm{g})$ were incubated with $\mathrm{L}_{\mathrm{CAT}}$ at a lipid and CAT concentrations of $400 \mu \mathrm{g} \mathrm{mL}^{-1}$ and $2.6 \mu \mathrm{g}$ $\mathrm{mL}^{-1}$, respectively. Following PDA coating, the CAT-loaded carriers where PEGylated with PLL-g-PEG at a GR of 3.2. The successful assembly was verified by measuring the $\zeta$-potential after each deposition step. At least two independent experiments were carried out.

The amount of CAT was quantified by incubating $9600 \mu \mathrm{g}$ of $M G / L_{\text {CAT }}$ in a solution of Triton X (1\% Triton X-100 in $200 \mu \mathrm{L}$ of Tris 2 buffer) for $30 \mathrm{~min}$. Next, the samples were spun down (30 $\min , 20000 \mathrm{~g}$ employing the high speed centrifuge) and $150 \mu \mathrm{L}$ of the supernatant were collected and analyzed by micro-BCA following the suppliers protocol. At least two independent experiments were carried out.

2.6.4. Combined antioxidant activity. $M G / L_{C A T} / P D A$ or $\mathrm{MG} / \mathrm{L}_{\mathrm{CAT}} / \mathrm{PDA} / \mathrm{PEG}$ in Tris 2 buffer $(800 \mu \mathrm{g}$ in $500 \mu \mathrm{L})$ were allowed to interact with $10 \mu \mathrm{L}$ of $\mathrm{KO}_{2}(0.14 \mathrm{mM})$ for different time intervals at $37{ }^{\circ} \mathrm{C}$ under continuous stirring. The samples were then spun down $(7 \mathrm{~min}, 4855 \mathrm{~g}$ ), the supernatants collected $(200 \mu \mathrm{L})$ and incubated with HRP $(100 \mu \mathrm{L}, 2 \mathrm{U} \mathrm{mL}-1$ in Tris 2 buffer) and Amplex Red ( $10 \mu \mathrm{L}, 0.1 \mathrm{mM}$ in Tris 2 buffer) for $5 \mathrm{~min}$ at $37^{\circ} \mathrm{C}$. The supernatants were collected $(200 \mu \mathrm{L})$ and the fluorescence intensity measured at excitation/emission wavelengths of 530/586 nm using the TECAN plate reader.

For the repeated enzymatic reaction, the MG/L $\mathrm{L}_{\mathrm{CAT}} / \mathrm{PDA}$ or $M G / L_{C A T} / P D A / P E G$ were allowed to interact with the $\mathrm{KO}_{2}$ solution for $30 \mathrm{~min}$ and the resorufin signal was measured as previously described. The carriers where then washed $(1 \times, 7$ $\min , 4855 \mathrm{~g}$ ) in Tris 2 and incubated again with a fresh $\mathrm{KO}_{2}$ solution to conduct a second round of enzymatic reaction. The process was repeated for five subsequent cycles. At least two independent experiments were carried out.

\subsection{Antioxidant activity in the presence of cells}

The mouse macrophage RAW 264.7 was cultured as previously described in section 2.5.4. and seeded at a density of 173000 cells per well in DMEM $(0.5 \mathrm{~mL})$ onto 24 -well plates. Prior conducting experiments, the cells were allowed to attach for 24 $\mathrm{h}$ at $37{ }^{\circ} \mathrm{C}$ and $5 \% \mathrm{CO}_{2}$. The statistical differences between the different conditions were evaluated using one-way ANOVA with a confidence level of $95 \%$ ( $\alpha=0.05$ ) using Tukey's multiple comparison posthoc test $(n=3 ; * p \leq 0.05 ; * * p \leq 0.01 ; * * * p \leq$ $0.001 ; * * * \mathrm{p} \leq 0.0001$ ) in a GraphPad Prism 7 software.

2.7.1. Optimization of $\mathrm{KO}_{2}$ concentration. After cell attachment, the cells were washed in PBS $(2 \times)$ and different concentrations of $\mathrm{KO}_{2}$ were added to each well of a 96-well plate and incubated for different time intervals at $3 \mathrm{C}_{\mathrm{w}}{ }^{\circ} \mathrm{C}$ a

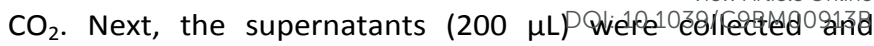
incubated with HRP (100 $\mu \mathrm{L}, 2 \mathrm{U} \mathrm{mL}^{-1}$ in PBS) and Amplex Red (10 $\mu \mathrm{L}, 0.1 \mathrm{mM}$ in PBS) for $5 \mathrm{~min}$ at $37^{\circ} \mathrm{C}$ under continuous stirring. The fluorescence intensity of the resorufin product was measured at excitation/emission wavelengths of $430 / 530 \mathrm{~nm}$ using the multimodal plate reader.

To assess the cell viability, the cells were washed in PBS $(2 \times$, $300 \mu \mathrm{L})$ and fresh medium $(270 \mu \mathrm{L})$ containing PrestoBlue ${ }^{\circledR}$ cell viability reagent $(30 \mu \mathrm{L})$ was added to each well following incubation for $1 \mathrm{~h}$ at $37^{\circ} \mathrm{C}$ in the dark. The fluorescent intensity of the reduced PrestoBlue ${ }^{\circledR}$ product was measured and the normalized cell viability calculated as previously described.

2.7.2. Non-enzymatic antioxidant activity. The cells were washed in PBS $(2 \times)$ and $500 \mu \mathrm{L}$ of PBS containing EDTA $\left(1 \times 10^{-}\right.$ $\left.{ }^{4} \mathrm{M}\right)$, cytochrome $\mathrm{C}\left(1 \times 10^{-5} \mathrm{M}\right)$, xanthine $\left(5 \times 10^{-5} \mathrm{M}\right)$, XO (11.6 $\mathrm{U} \mathrm{mL} \mathrm{m}^{-1}$ ) and $796 \mu \mathrm{g}$ of $\mathrm{MG} / \mathrm{L}_{\mathrm{CAT}} / \mathrm{PDA} / \mathrm{PEG}$ were added to the wells and incubated for $2 \mathrm{~h}$ at $37{ }^{\circ} \mathrm{C}$ and $5 \% \mathrm{CO}_{2}$. After the incubation time, the supernatants were collected $(100 \mu \mathrm{L})$ and the reduced cytochrome $\mathrm{C}$ was monitored at $550 \mathrm{~nm}$ employing the multimode plate reader. Fluorescently labelled $L_{\text {CAT }}$ were used for quantification purposes.

The viability of the cells after enzymatic reaction was performed as described in section 2.5.5.

2.7.3. Combined antioxidant activity. Following cell attachment, the cells were washed in PBS $(2 \times)$ and incubated in a $\mathrm{KO}_{2}$ solution $\left(500 \mu \mathrm{L}, 0.1 \mathrm{mg} \mathrm{mL}^{-1}\right)$ containing $796 \mu \mathrm{g}$ of $\mathrm{MG} / \mathrm{L}_{\text {CAT }} / \mathrm{PDA} / \mathrm{PEG}$ and incubated for $2 \mathrm{~h}$ at $37{ }^{\circ} \mathrm{C}$ and $5 \% \mathrm{CO}_{2}$. After the incubation time, the supernatants $(200 \mu \mathrm{L})$ were collected and incubated with $\mathrm{HRP}\left(100 \mu \mathrm{L}, 2 \mathrm{U} \mathrm{mL}^{-1}\right.$ in PBS) and Amplex Red (10 $\mu \mathrm{L}, 0.1 \mathrm{mM}$ in PBS) for $5 \mathrm{~min}$ at $37{ }^{\circ} \mathrm{C}$ under continuous stirring. Finally, the fluorescence intensity of the resorufin product $\left(\lambda_{\mathrm{ex}}=570 \mathrm{~nm}, \lambda_{\mathrm{em}}=615 \mathrm{~nm}\right.$ ) was measured at excitation/emission wavelengths of $430 / 530 \mathrm{~nm}$ using the multimode plate reader. Fluorescently labelled $\mathrm{L}_{\text {CAT }}$ were used for quantification purposes.

The viability of the cells after enzymatic reaction was performed as described in section 2.5.5.

\section{Results and Discussion}

\subsection{Fabrication of a dual-component carrier}

3.1.1. Liposome deposition. To achieve a high cargo loading, we first sought to identify the highest amount of fluorescently labelled $L^{F}$ that could be adsorbed onto the MGs without promoting aggregation of the system. To do that, a suspension of negatively charged MGs was incubated with increasing amounts of positively charged $\mathrm{L}^{\mathrm{F}}$ and the mean fluorescence intensity (MFI) of the $\mathrm{MG} / \mathrm{L}^{\mathrm{F}}$ assemblies was monitored by flow cytometry.

Since such a dual-component carrier is envisioned to perform inside the body, the liposomes (L) were constituted by a lipid mixture displaying a liquid-to-gel phase transition temperature $\left(\mathbf{T}_{m}\right)$ close to $37^{\circ} \mathrm{C}$ which will allow for the diffusion of substrates and products in and out the carrier. Thus, we employed DMPC $\left(\mathrm{T}_{m} \sim 24{ }^{\circ} \mathrm{C}\right)$, DPPC $\left(\mathrm{T}_{m}\right.$ $\left.\sim 41{ }^{\circ} \mathrm{C}\right)$ and positively charged DSTAP $\left(\mathrm{T}_{m} \sim 50-60{ }^{\circ} \mathrm{C}\right)$ in a $6.5: 2.5$ : 1.0 weight ratio. Upon addition of a fluorescent lipid, $L^{F}$ with a 
a)

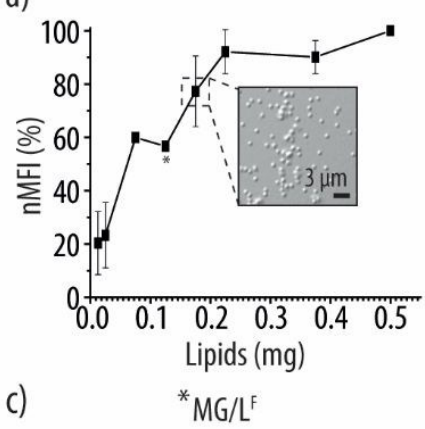

b)

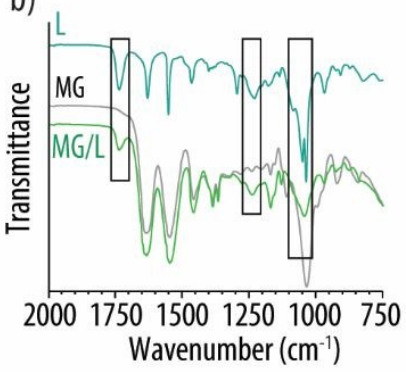

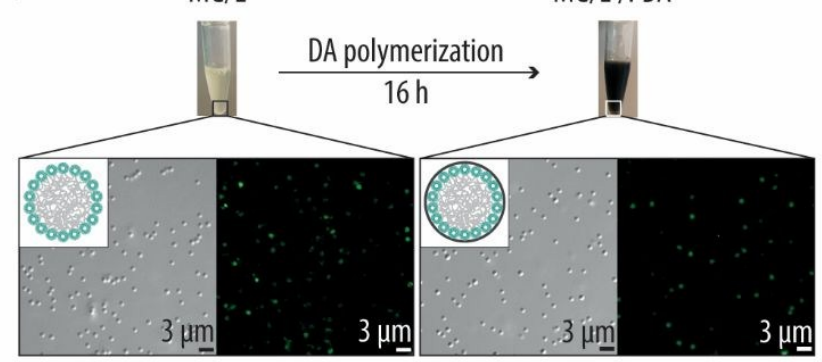

d) $M G$

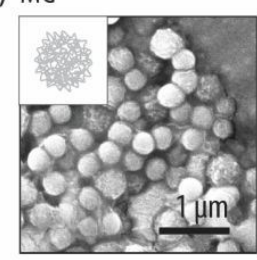

$\mathrm{MG} / \mathrm{L}^{\mathrm{E}}$

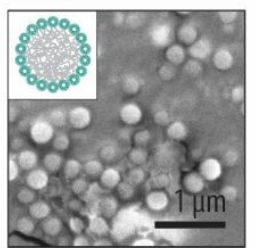

$M G / L / P D A$

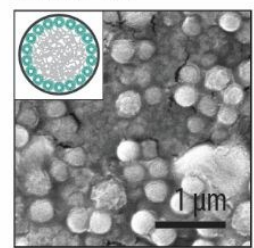

Figure 1. a) Normalized mean fluorescence intensity (nMFI) readings of microgels (MGs) incubated with increasing amounts of fluorescently labelled liposomes $\left(\mathrm{L}^{\mathrm{F}}\right)$, expressed in amount of lipids. The inset shows a differential interference contrast (DIC) image of an aggregated MG/LF assembly. b) Fourier-transform infrared (FTIR) spectra after liposome deposition. c) Deposition of a poly(dopamine) (PDA) coating as a result of the self-polymerization of dopamine (DA). Differential interference contrast and fluorescence microscopy images of $\mathrm{MG} / \mathrm{L}^{\mathrm{F}}$ before (left) and after (right) the PDA coating. d) Scanning electron microscopy images of the different coating steps.

diameter of $111 \pm 7 \mathrm{~nm}$ and a positive $\zeta$-potential of $46 \pm 3 \mathrm{mV}$ were obtained. The $L^{F}$ were then absorbed onto MGs displaying a diameter of $740 \pm 17 \mathrm{~nm}$ and a negative $\zeta$-potential of $-32 \pm 1 \mathrm{mV}$. The results, which have been normalized to the MFI readings for the highest amount of added lipids (nMFI), show saturation of the nMFI upon incubating the MGs with $\mathrm{L}^{\mathrm{F}}$ constituted by $0.225 \mathrm{mg}$ of lipids (Figure 1a). However, DIC images show already sample aggregation for lower lipid amounts (i.e., $0.175 \mathrm{mg}$ ) (Figure 1a, inset). Thus, the lower ratio of $0.125 \mathrm{mg}$ lipids per $0.48 \mathrm{mg}$ of MGs was employed to construct the dual-component carrier. The $M G / L$ assemblies were further characterized by FTIR spectroscopy. Figure $1 \mathrm{~b}$ shows the FTIR spectra of the liposome deposition. The MG spectrum shows characteristic peaks at 1630 ( $\mathrm{C}=\mathrm{O}$ stretching), 1545 ( $\mathrm{C}-\mathrm{N}$ stretching), $1460\left(-\mathrm{CH}_{3}\right.$ bend), 1385 and $1365 \mathrm{~cm}^{-1}$ (- $\mathrm{CH}_{3}$ deformation), which is in accordance with the PNIPAM polymer. ${ }^{35,36}$ For the L spectrum, characteristic peaks are present at 1735 ( $\mathrm{C}=\mathrm{O}$ stretching), $1230\left(\mathrm{PO}_{2^{-}}\right.$ asymmetric stretching), and $1050-1040 \mathrm{~cm}^{-1}\left(\mathrm{PO}_{2^{-}}\right.$symmetric stretching). ${ }^{37}$ These peaks are also present in the $\mathrm{MG} / \mathrm{L}$ spectrum, suggesting successful deposition of $L$ onto the MG.

3.1.2. PDA coating. A protective coating shell is needed to protect

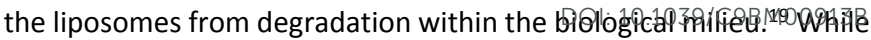
prior reports on multicompartment carriers employed alternating polymer layers deposited by the layer-by-layer technique to create the carrier shell; ${ }^{14}$ we will make use of the deposition of PDA. The PDA adsorption, which is conducted in a single step, considerably facilitates the assembly process. We, and others, have previously reported the assembly of carriers consisting of thousands of liposomes embedded within a PDA shell and demonstrated their ability to act as microreactors performing (multiple) enzymatic reactions. ${ }^{26,38}$ The MG/LF assemblies were incubated in a DA solution in Tris 1 buffer for $16 \mathrm{~h}$. Figure 1c shows DIC and fluorescence microscopy images of the $M G / L^{F}$ assemblies before (left side) and after (right side) PDA coating. While the dark colour of the test tube confirms the deposition of PDA, the microscopy images demonstrate good colloidal stability for the $\mathrm{MG} / \mathrm{L}^{\mathrm{F}}$ assemblies. We would like to note that in order to detect the fluorescent $L^{F}$ through the dark PDA coating a rather high amount of fluorescent lipids (i.e., $2 \mathrm{wt} \%$ of NBDPC) has been employed. Importantly, the colloidal stability is not compromised by the PDA coating. SEM images revealed that MG, $M G / L$ and MG/L/PDA samples were uniform in size all of them displaying a smooth and uniform structure (Figure 1d).

\subsection{Surface functionalisation}

3.2.1. PEGylation. To act as a microreactor depleting ROS in the vasculature, achieving long-circulation in the blood stream is a central aspect. However, the adsorption of proteins with an opsonic effect onto the carrier's surface will increase the chances of being cleared from the body by the mononuclear phagocyte system (MPS). Modification of the carriers surface with low-fouling polymers such as PEG, has emerged as the golden strategy to diminish opsonin adsorption. ${ }^{39}$

Since PDA can be easily functionalized by amines and thiols, ${ }^{40}$ a convenient method for the covalent immobilization of PEG is by making use of PLL-g-PEG co-polymers. ${ }^{28,29}$ As a follow up study to our previous report, ${ }^{28}$ herein we investigate the PEGylation effect depending on the employed GR. Three PLL-g-PEG differing on the GR $(3.2,2.5$ and 1.6, respectively) are employed to create MG/L/PDA/PEG carriers. Since protein resistance becomes increasingly efficient the more the PEG chains overlap, we decided to employ lower GRs than in our prior report. ${ }^{28}$ The coating of the carriers surface was first assessed by $\zeta$-potential measurements (Figure 2a). The bare MGs, as expected, rendered an overall negative charge of $-32.1 \pm 1.5 \mathrm{mV}$. Upon deposition of the positively charged $\mathrm{L}$, an increase in $\zeta$-potential to $-24.1 \pm 1.9 \mathrm{mV}$ was observed. A further increase in $\zeta$-potential up to $-17.9 \pm 0.6 \mathrm{mV}$ was observed following PDA coating. Although, unaltered $\zeta$-potential for PDA deposition onto positively charged liposomes has been previously reported, ${ }^{29}$ we attribute our pronounced increase in $\zeta$-potential to the longer polymerization time for PDA (i.e., $\sim 16 \mathrm{~h}$ vs $\sim 75 \mathrm{~min}$ of previous reports). Comparison of the FTIR spectra before and after surface modification with PEG was employed (Figure $2 b$ ). PLL- $g$-PEG shows characteristic peaks at 1340 (ether $\mathrm{CH}_{2}$ wagging), 1105 (C-O-C stretching), and $960 \mathrm{~cm}^{-1}$ (ether $\mathrm{CH}_{2}$ rocking). ${ }^{33}$ These can also be found in the spectrum of MG/L/PDA/PEG, further indicating successful deposition of PLL-g-PEG. 

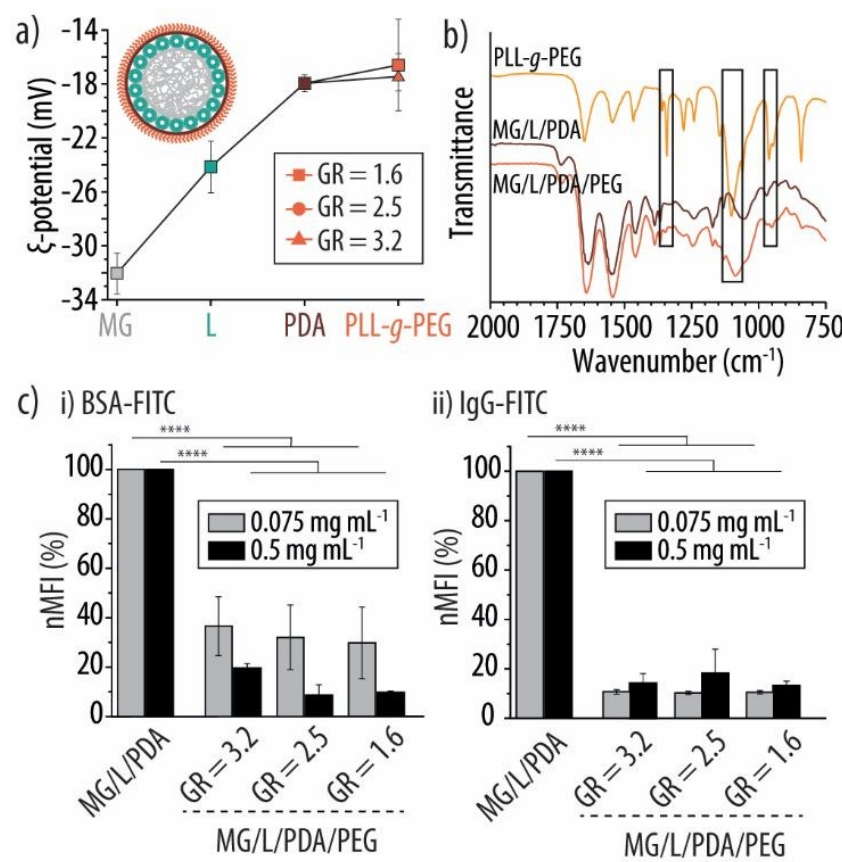

ii) $\lg$ G-FITC Wavenumber $\left(\mathrm{cm}^{-1}\right)$

d)
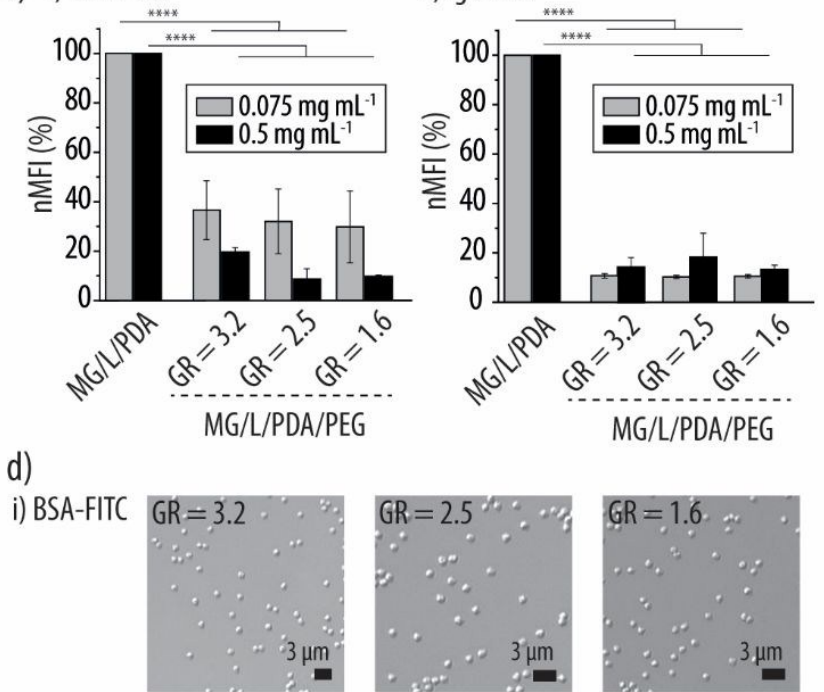

ii) $\lg \mathrm{G}-\mathrm{FITC} \quad \mathrm{GR}=3.2$
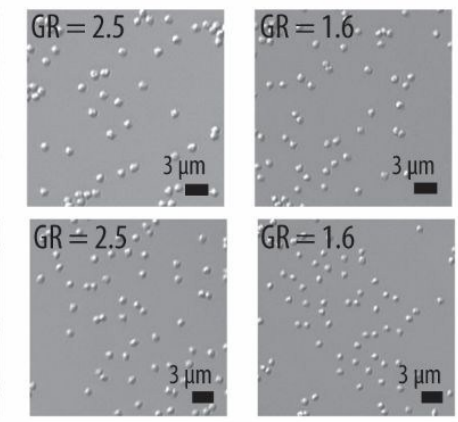

Figure 2. a) Zeta (そ)-potential measurements of microgels (MGs) after the deposition of liposomes (L), a poly(dopamine) (PDA)-coating and the co-polymer poly-L-lysinegraft-poly(ethylene glycol) (PLL-g-PEG) at three different grafting ratios (GRs). b) Fourier-transform infrared (FTIR) spectra of the assemblies before (MG/L/PDA) and after (MG/L/PDA/PEG) modification with PLL-g-PEG. c) Normalized mean fluorescence intensity (nMFI) of bare (MG/L/PDA) and PEGylated (MG/L/PDA/PEG) carriers at the three different GRs upon being incubated with fluorescein isothiocyanate (FITC)-labelled bovine serum albumin (BSA) (BSA-FITC) (i) and immunoglobulin G (IgG-FITC) (ii) at two different concentrations. At least three independent experiments were carried out in triplicate $(n=3),{ }^{*} p \leq 0.05 ;{ }^{* *} p \leq 0.01$; $* * * p \leq 0.001 ; * * * * p \leq 0.0001$. d) Differential interference contrast (DIC) images of the MG/L/PDA/PEG carriers at the different GRs after being incubated with BSA-FITC (i) or IgG-FITC (ii) at the highest studied concentration $\left(0.5 \mathrm{mg} \mathrm{mL}^{-1}\right)$.

3.2.2. Protein adsorption. We next assessed the PEGylation effect of the surface coating in terms of protein adsorption depending on the GR. Specifically, MG/L/PDA/PEG carriers coated with PLL-g-PEG at a GR of $3.2,2.5$ or 1.6 were incubated for $4 \mathrm{~h}$ at $37^{\circ} \mathrm{C}$ with BSA and IgG which are two of the most abundant proteins in blood. The proteins were fluorescently labelled to render BSA-FITC and IgG-FITC and their attachment onto the carriers was followed by flow cytometry. Two different concentrations commonly employed in literature (i.e., 0.075 and $\left.0.5 \mathrm{mg} \mathrm{mL}^{-1}\right)^{41,42}$ were evaluated. In contrast to IgG, which is believed to act as a potent opsonin, albumin is thought to have an early dysopsonic effect thus decreasing mononuclear phagecyte $_{\text {pha }}$

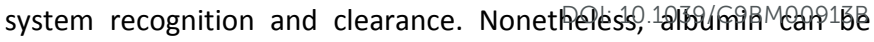
easily replaced by other proteins with opsonic effect. ${ }^{43}$ The results, which have been normalized to the BSA-FITC and IgG-FITC binding to MG/L/PDA at the two studied protein concentrations, are shown in Figure 2c. For all three studied GR, surface functionalization with PLL$g$-PEG leads to a marked decrease in nMFI independent of the protein concentration. Figure 2ci shows how exposure of MG/L/PDA/PEG to BSA-FITC leads to a decrease of $75 \%$ (for 0.075 $\mathrm{mg} \mathrm{mL}^{-1}$ ) and $~ 80-90 \%$ (for $0.5 \mathrm{mg} \mathrm{mL}^{-1}$ ) in $\mathrm{nMFI}$, independent of the GR. When incubating MG/L/PDA/PEG with IgG-FITC, a decrease of $\sim 90-85 \%$ in $\mathrm{nMFl}$ is observed with no differences depending on the GR or protein concentration (Figure 2cii). These results highlight the efficient protection rendered by PLL- $g$-PEG against protein deposition for the three studied GRs. Finally, DIC images revealed that the presence of the most abundant protein and immunoglobulin in blood did not affect the colloidal stability in terms of aggregation (Figure 2d and Figure S2, Supporting Information).

3.2.3. Cellular uptake/association. The PEGylation effect was further investigated in vitro by the ability of the coating to avoid/minimize cell uptake or association. We chose as model cell lines human endothelial (HUVEC) and the murine macrophages RAW 264.7 cell lines. While endothelial cells are the cells lining our blood vessels, circulating macrophages are the first line of defence of the human body against intruding pathogens. To compare the uptake of uncoated and PEGylated carriers depending on the GRs, $3.7 \mathrm{ng}$ per cell of fluorescently labelled $\mathrm{MG} / \mathrm{LF}^{\mathrm{F}} / \mathrm{PDA}$ and $\mathrm{PEGylated}$ $\mathrm{MG} / \mathrm{L}^{\mathrm{F}} / \mathrm{PDA} / \mathrm{PEG}$ at the three different $\mathrm{GRs}$ were incubated with the two cell lines for $4 \mathrm{~h}$ at $37{ }^{\circ} \mathrm{C}$. The cell mean fluorescence intensity (CMFI) readings were assessed by flow cytometry and normalized (nCMFI) to the cells exposed to MG/LF/PDA (Figure 3). The cellular uptake efficiency (CUE), which is determined as the percentage of cells with a CMFI higher than the auto fluorescent level of the cells, was also evaluated.

In agreement with the protein resistance results, for both cell lines PEGylation of the carriers results in a significant decrease in both nCMFI and CUE which also shows to be independent of the GR employed. When incubating the RAW 264.7 cells with the PEGylated carriers, a very similar decrease in nCMFI ( $\sim 5 \%$ ) and CUE ( $25 \%)$ was observed for both 3.2 and $2.5 \mathrm{GRs}$. In contrast, a GR of 1.6 produced a less pronounced decrease in both nCMFI and CUE (of 30\% and $\sim 15 \%$, respectively). However, no significant differences were found for the three different GRs, suggesting an equal ability to diminish cell uptake (Figure 3ai and ii). For HUVEC cells a more pronounced decrease in both nCMFI (of $\sim 50-55 \%$ ) and CUE ( $\sim 40 \%$ ) as compared to RAW 264.7 cells was observed (Figure 3bi and ii). Such a decrease was also independent of the GRs.

Although only a systematic study spanning the range of different GRs but also including polymer length and sizes, geometries and elasticities of the carriers will allow for proper comparison, our reported system shows one of the highest PEGylation effects in terms of protein resistance and cell uptake for carriers decorated with the PLL-g-PEG co-polymer. 22,28,29 Importantly, we also assessed the effect of the dual-component carriers on cell viability by the two cell lines and we found no significant decrease in cell viability of the uncoated and PEGylated carriers at the different GR. 
Since the PEGylation effect appears to be independent of the employed GRs, only one PLL-g-PEG polymer (with a GR $=3.2$ ) will be used for the next experiments.

\subsection{Functional performance.}

Despite ROS crucial roles in central physiological processes, elevated ROS levels are correlated with a variety of diseases. To mitigate the burden of enzymes, within living organisms non-enzymatic biomolecules such as tocopherols, biothiols or flavonols, contribute to the preservation of intercellular homeostasis. ${ }^{44}$ Thus, in our body, antioxidative biomolecules work together with antioxidant enzymes
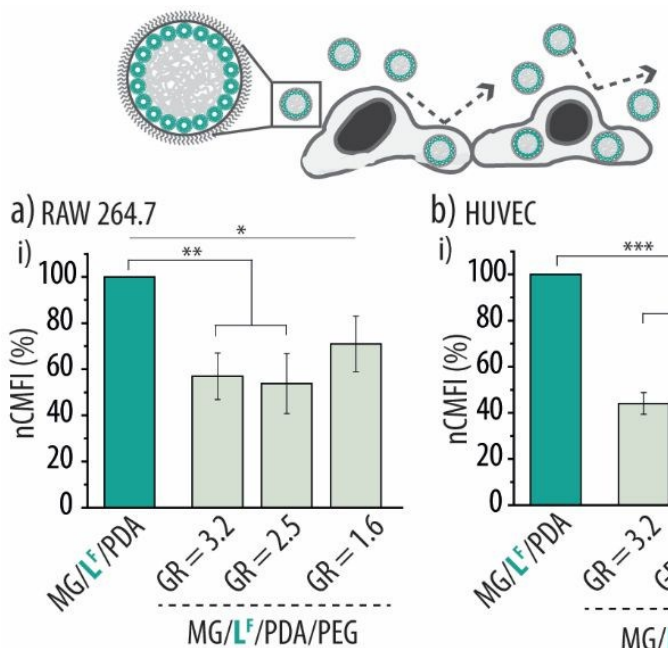

b) HUVEC
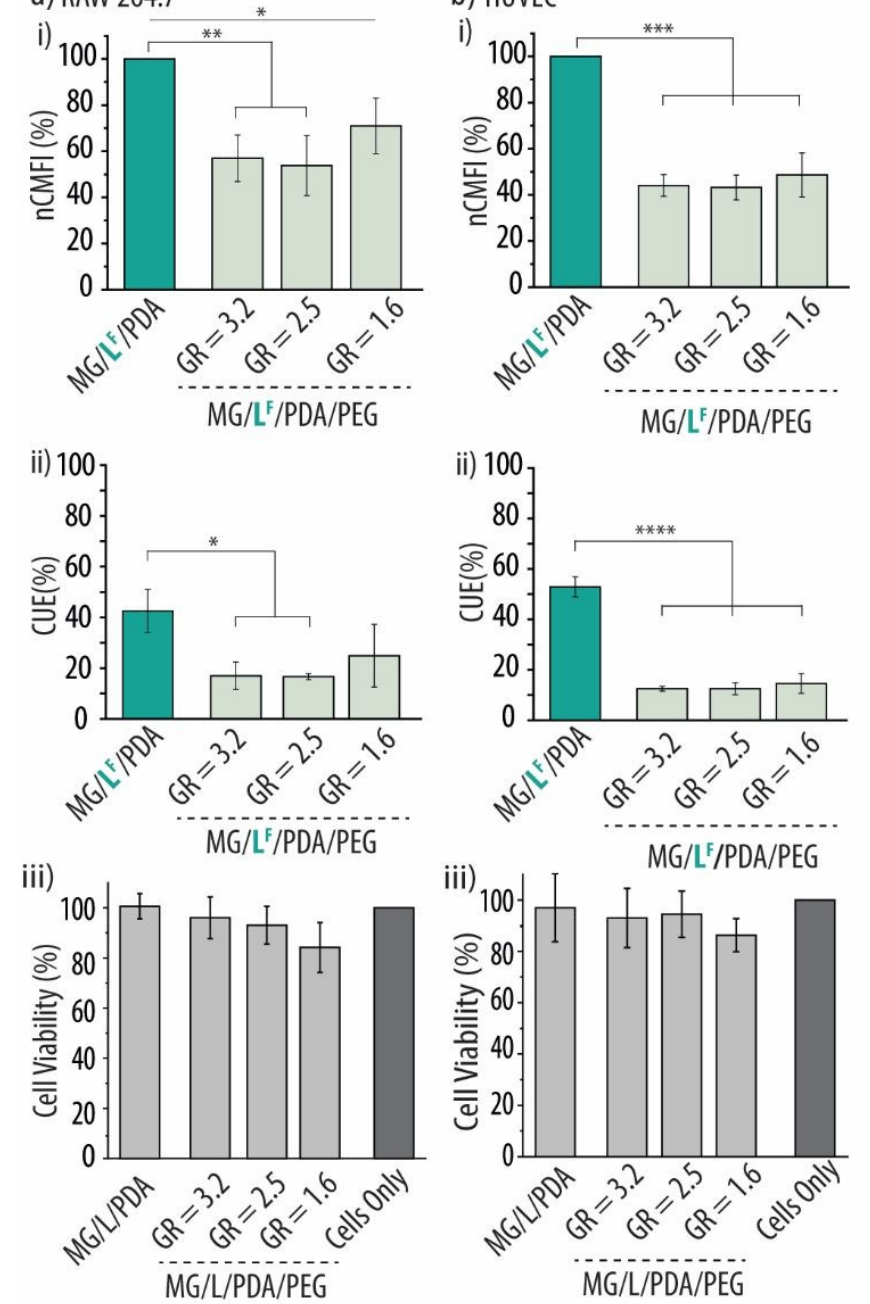

Figure 3. i) Normalized cell mean fluorescence intensity (nCMFI), ii) cell uptake efficiency (CUE) and iii) cell viability for RAW 264.7 (a) and HUVEC (b) cells upon exposure to uncoated (MG/LF/PDA) or PEGylated (MG/LF/PDA/PEG) carriers. PEGylated carriers have been assembled with PLL-g-PEG at three different grafting ratios (GRs). Fluorescently labelled liposomes $\left(L^{F}\right)$ have been employed to construct the carriers. At least three independent experiments were carried out in triplicate ( $\mathrm{n}$ $=3),{ }^{*} p \leq 0.05 ;{ }^{* *} p \leq 0.01 ; * * * p \leq 0.001 ; * * * * p \leq 0.0001$.

to create a powerful machinery to protect against oxidative damage caused by overexpressed ROS. However, past research efforts to minimize oxidative stress, have mainly focused in making use iof either antioxidant enzymes or non-enzymatic: bntroxidants alohe, and the combination of the two systems within an integrated platform has remained largely unexplored.

Herein, inspired by nature, we assess the potential of the dualcomponent carriers in reducing ROS levels by combining both antioxidant enzymes and non-enzymatic compounds. We make use of the CAT enzyme by entrapping it within the liposomal subcompartments, while the PDA coating acts as a non-enzymatic antioxidant compound. Thus, PDA serves as a synthetic mimic of naturally occurring melanins displaying excellent biocompatibility and antioxidant properties. ${ }^{45}$ Melanins, due to their distinct free radical character, are considered as efficient antioxidants present in biological systems. ${ }^{30}$

3.3.1. Non-enzymatic antioxidant activity. We first evaluated the potential antioxidant activity of the dual-component carrier due to the PDA coating. PDA, similar to melanin, has reported the ability to remove toxic ROS such as ${ }^{\circ} \mathrm{OH}$ or $\mathrm{O}_{2}{ }^{\bullet} \cdot{ }^{30} \mathrm{It}$ is believed that the efficient catalysis of the $\mathrm{O}_{2}{ }^{\cdot-}$ dismutation into $\mathrm{O}_{2}$ and $\mathrm{H}_{2} \mathrm{O}_{2}$ by melanin-like structures is due to the stable unpaired electrons at the centre of the stacked units, which could act as catalytic centres for electron removal. ${ }^{46}$

The reaction kinetics of the $\mathrm{O}_{2}{ }^{--}$depletion by the dual-component carrier were elucidated making use of the cytochrome $\mathrm{C}$ assay. The method relies on the ability of xanthine and the XO enzyme to generate $\mathrm{O}_{2}{ }^{--}$from $\mathrm{O}_{2}$. Next, the oxidised form of cytochrome $\mathrm{C}$ (cytochrome ${ }^{3+} \mathrm{C}$ ) is reduced by $\mathrm{O}_{2}{ }^{--}$to the yellow cytochrome ${ }^{2+} \mathrm{C}$, which can be detected by its characteristic absorbance peak at 550 nm (Figure 4). In particular, either MG/L/PDA or MG/L/PDA/PEG were incubated in a reaction mixture containing cytochrome ${ }^{3+} \mathrm{C}$, xanthine and $\mathrm{XO}$ for up to $2 \mathrm{~h}$ at $37{ }^{\circ} \mathrm{C}$. As controls, the reaction mixture only (blank) and the uncoated $\mathrm{MG} / \mathrm{L}$ carriers were considered. Figure 4a shows the absorbance signal due to the yellow cytochrome ${ }^{2+} \mathrm{C}$ product after 0.5 and $2 \mathrm{~h}$ of incubation. The results, which have been normalized to the blank (nAbsorbance), show a decrease in nAbsorbance for both PEGylated and non-PEGylated carriers at the two studied time points. Interestingly, MG/L/PDA lead to a more pronounced decrease in nAbsorbance as compared to MG/L/PDA/PEG. Although we cannot explain these results yet, we speculate that such differences could be due to the modification of the PDA structure by the PEG coating. DIC images taken after $2 \mathrm{~h}$ of conversion demonstrated preservation of both structural integrity and colloidal stability of the carriers (Figure $4 a$, inset).

We next tested whether the dual-component carriers were able to sustain multiple rounds of $\mathrm{O}_{2}{ }^{\bullet-}$ dismutation. This is an important aspect since, for the envisioned application, such carriers are expected to deplete ROS within the vasculature in a sustained manner As such, the reaction was run in the same conditions as for the kinetics experiments but, after 30 min of incubation, the samples were spun down, the supernatants collected and the absorbance due to the yellow cytochrome ${ }^{2+} \mathrm{C}$ measured. Next, the samples were washed and incubated again with the reaction mixture for $30 \mathrm{~min}$. This procedure was repeated for five subsequent cycles and the same controls as for the kinetics experiment (blank and MG/L) were considered. The results, which have been normalized to the 
absorbance of the blank after each cycle, show a decrease in nAbsorbance of $~ 52 \%$ and $~ 32 \%$ for MG/L/PDA and MG/L/PDA/PEG, respectively, for the first cycle (Figure $4 b$ ). For the second cycle, a less pronounced decrease in nAbsorbance for MG/L/PDA (of 25\%) was observed, indicating a slight loss of activity. However, no differences in nAbsorbance were observed for MG/L/PDA/PEG as compared to cycle 1. Additionally, similar decrease in nAbsorbance for the next rounds is observed. The absence of a further loss of activity for the three next rounds highlights the robustness of this carrier, since it is able to display catalytic activity even after being several spinning and resuspension cycles.

3.3.2. CAT encapsulation. Once the non-enzymatic activity of the dual-component carriers had been evaluated, we sought to

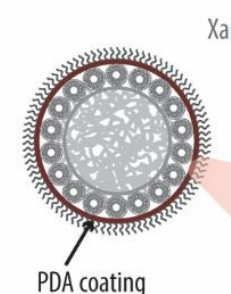

Xanthine $+\mathrm{O}_{2} \quad 2 \mathrm{O}_{2}$ Cytochrome ${ }^{2+} \mathrm{C}+\mathrm{O}_{2}$

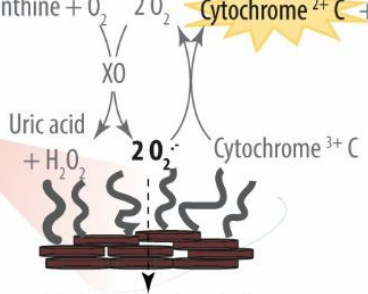

$\mathrm{H}_{2} \mathrm{O}_{2}+$ mix of products
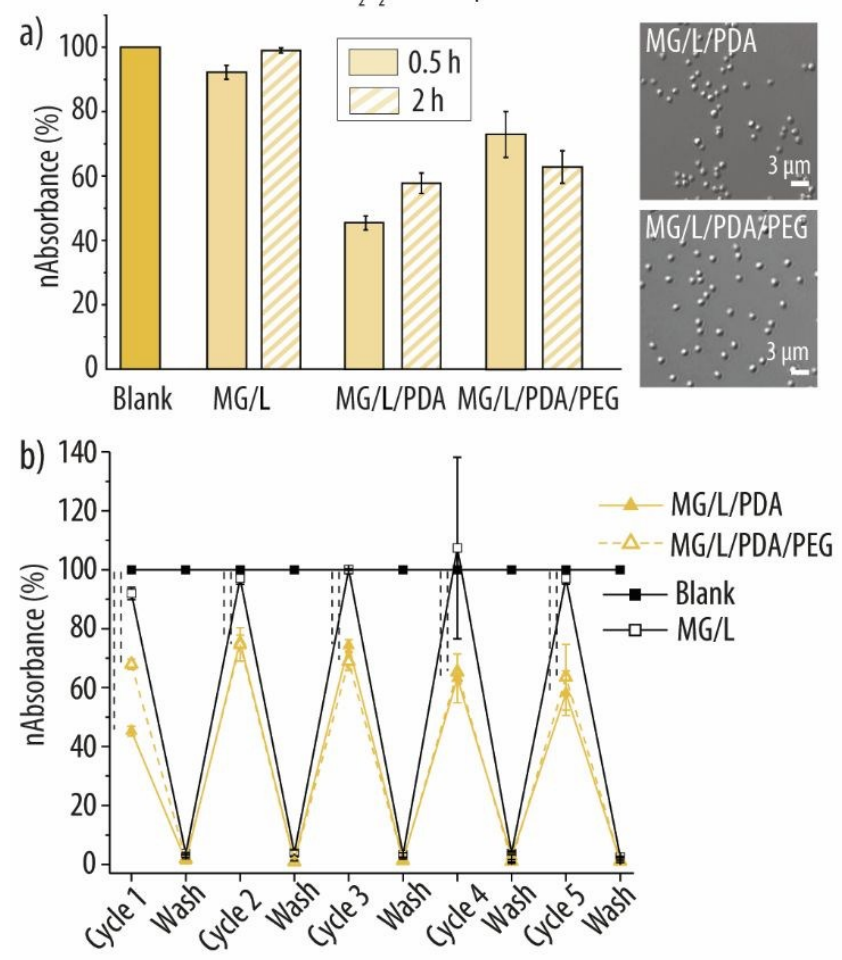

Figure 4. a) Antioxidant activity towards the superoxide radical $\left(\mathrm{O}_{2}{ }^{-}\right)$of uncoated MG/L/PDA and PEGylated MG/L/PDA/PEG carriers over time due to the poly(dopamine) (PDA) coating. As controls, carriers without the PDA coating MG/L and reaction mixture only (blank) are considered. The insets show DIC images of the uncoated MG/L/PDA and PEGylated MG/L/PDA/PEG carriers after $2 \mathrm{~h}$ of enzymatic reaction. b) Antioxidant activity towards $\mathrm{O}_{2}{ }^{*}$ of the different carriers for five subsequent cycles. The detection method is based on the oxygen $\left(\mathrm{O}_{2}\right)$ conversion into $\mathrm{O}_{2}{ }^{*-}$ by the xanthine/ xanthine oxidase (XO) system. $\mathrm{O}_{2}{ }^{*}$, in turn, oxidises the cytochrome $^{3+} \mathrm{C}$ substrate into cytochrome ${ }^{2+} \mathrm{C}$ which can be detected spectrophotometrically at $550 \mathrm{~nm}$. As a result of the antioxidant PDA-coating, $\mathrm{O}_{2}{ }^{-}$is consumed, thus diminishing the amount of oxidized cytochrome ${ }^{2+} \mathrm{C}$. encapsulate an antioxidant enzyme to combine both enzymatisand

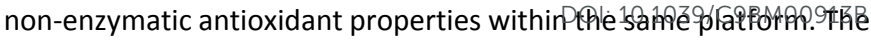
CAT enzyme was chosen due to its ability to catalyse the decomposition of the generated first reaction product (i.e., $\mathrm{H}_{2} \mathrm{O}_{2}$ ).

Prior to assembling the enzyme-loaded microreactors, we investigated the CAT entrapment within liposomes. Liposomes, which are composed by a lipid bilayer resembling the membrane of living cells, are particularly well suited for enzyme encapsulation by protecting them from misfolding and the associated denaturation. ${ }^{19}$ $\mathrm{L}_{\text {CAT }}$ were fabricated with the previously described lipid mixture and several CAT concentrations were employed to identify the maximum loading. Following removal of the non-encapsulated/associated CAT by size exclusion chromatography, $L_{C A T}$ were disassembled with Triton- $X$ and the total protein amount was quantified by means of the micro-BCA assay. Figure 5a shows that the maximum amount of
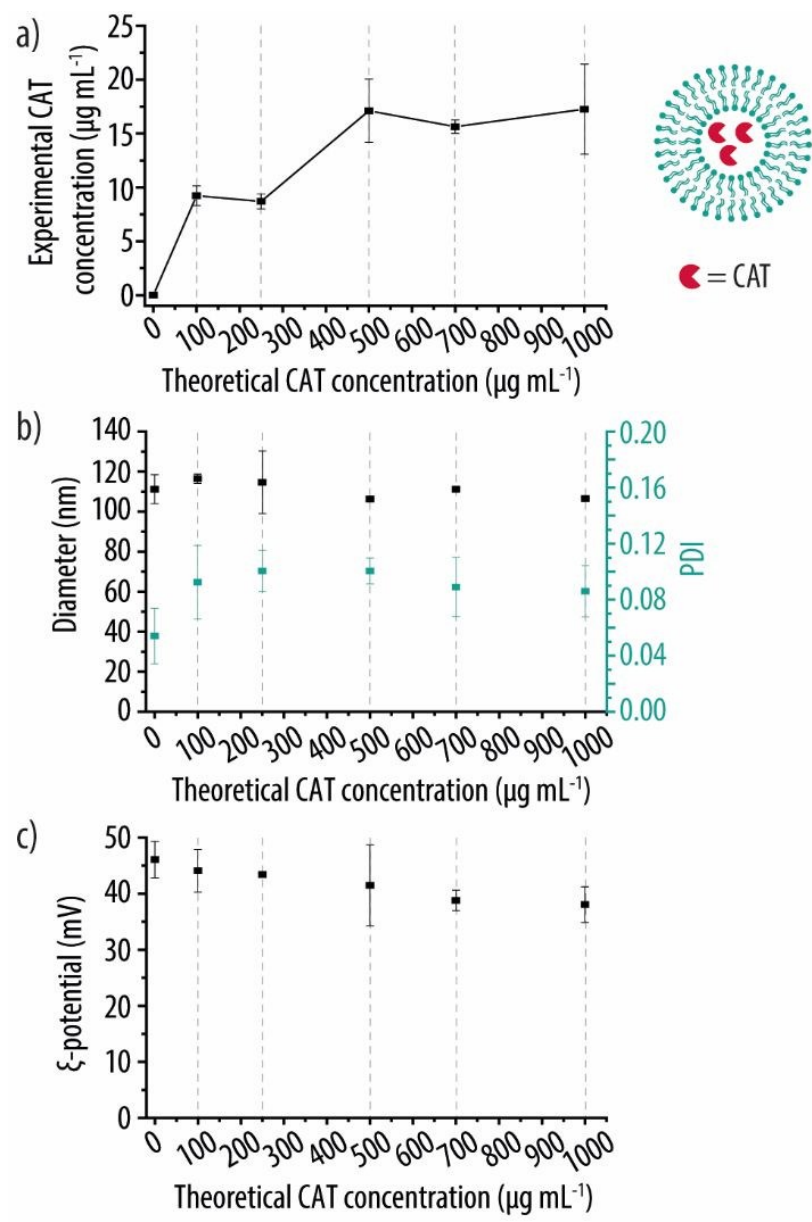

Figure 5. a) Liposomes loaded with different amounts of the catalase (CAT) enzyme are ruptured by the addition of Triton $X$, and the experimental concentration of CAT within the liposomes is evaluated by a bicinchoninic acid assay. b) The diameter and polydispersity index (PDI) of liposomes entrapping increasing CAT amounts are assessed by dynamic light scattering measurements. c) Zeta (Ъ)-Potential measurements of liposomes entrapping increasing amounts of CAT.

CAT that could be entrapped was $\sim 17 \mu \mathrm{g} \mathrm{mL} \mathrm{L}^{-1}$ for liposomes assembled with a $2.5 \mathrm{mg} \mathrm{mL}^{-1}$ lipid concentration. This resulted in an EE of $3.0 \pm 0.8 \%$ (for details see Supporting Information). While this EE seems rather low, it is in agreement with other EE reported for $\mathrm{CAT}^{47}$ and could be attributed to its large size of $\sim 250 \mathrm{kDa}$. Next, $\mathrm{L}_{\text {CAT }}$ 
were characterized by DLS to assess both their size and PDI (Figure $5 b)$. The different $L_{C A T}$ displayed diameters ranging from $\sim 110$ to $\sim 120 \mathrm{~nm}$, independent of the CAT concentration. Similarly, low PDI values ( 0.09-0.11) were also obtained for all the studied CAT concentrations. An exception were the empty liposomes, which displayed a PDI of only $\sim 0.05$. The $\zeta$-potential was also evaluated and, due to CAT's negative charge at physiological $\mathrm{pH}$, a slight decrease in $\zeta$-potential was observed for $L_{C A T}$ as compared to the empty liposomes (Figure $5 \mathrm{C}$ ). Thus, $\mathrm{L}_{\mathrm{CAT}}$ assembled with a CAT concentration of $500 \mu \mathrm{g} \mathrm{mL}-1$ were chosen for the carriers fabrication since saturation was reached with such a concentration. The dualcomponent carriers were assembled as previously described but replacing empty liposomes by $L_{\text {CAT }}$. The successful assembly was verified by $\zeta$-potential measurements after each deposition step and characterized by DIC and fluorescence microscopy, FTIR and SEM (Figure S3, Supporting Information). The total amount of CAT per $\mu \mathrm{g}$ of MGs was identified as $0.83 \mu \mathrm{g}$ by the BCA assay.

3.3.3. Combined antioxidant activity. Following the successful assembly of the CAT-loaded dual-component carriers, we then investigated their multi-antioxidative properties. While the PDA coating, similar to melanin, could catalyse the dismutation of $\mathrm{O}_{2}{ }^{--}$ into $\mathrm{H}_{2} \mathrm{O}_{2}$, CAT was selected as the antioxidant enzyme due to its ability to decompose the as-produced $\mathrm{H}_{2} \mathrm{O}_{2}$ into non-toxic $\mathrm{O}_{2}$ and $\mathrm{H}_{2} \mathrm{O}$.

The catalysed cascade reaction was monitored by means of the Amplex Red assay, where $\mathrm{H}_{2} \mathrm{O}_{2}$ acts as a co-substrate for the oxidation of Amplex Red by HRP into the fluorescent resorufin product (Figure 6). In particular, $M G / \mathrm{L}_{\mathrm{CAT}} / \mathrm{PDA}$ or $\mathrm{MG} / \mathrm{L}_{\mathrm{CAT}} / \mathrm{PDA} / \mathrm{PEG}$ CAT-loaded microreactors were allowed to interact with $\mathrm{O}_{2}{ }^{\circ-}$ at 37 ${ }^{\circ} \mathrm{C}$. At different time points, the samples were centrifuged, the supernatants collected and further incubated with a solution containing HRP and Amplex Red for 5 min at $37^{\circ} \mathrm{C}$. The MFI readings due to the fluorescent resorufin product were measured and normalized to the highest MFI reading (Figure 6a). The kinetics of $M G / L_{C A T} / P D A$ and $M G / L_{C A T} / P D A / P E G$ were compared to the empty $\mathrm{MG} / \mathrm{L} / \mathrm{PDA}$ and MG/L/PDA/PEG carriers and to the uncoated MG/L carriers. A blank consisting of the reaction mixture without carriers was also considered. As expected, the highest nMFI signal was obtained for the empty microreactors (MG/L/PDA and $\mathrm{MG} / \mathrm{L} / \mathrm{PDA} / \mathrm{PEG}$ ) due to the conversion of $\mathrm{O}_{2}{ }^{-}$into $\mathrm{H}_{2} \mathrm{O}_{2}$ by the PDA coating (Figure $6 a$, red lines). Interestingly, while MG/L/PDA gave rise to $100 \% \mathrm{nMFI}$ after $15 \mathrm{~min}, \mathrm{MG} / \mathrm{L} / \mathrm{PDA} / \mathrm{PEG}$ only generated $\sim 45 \%$ nMFI under the same conditions. Although we cannot fully understand this divergence, these results are in agreement with Figure 4 and could be due to the different redox activity of PDA following covalent modification with PLL-g-PEG. Both the blank and $\mathrm{MG} / \mathrm{L}$ controls gave a residual $\mathrm{nMFI}$ of $\sim 20 \%$ (Figure $6 \mathrm{a}$, black lines), which could be due to the spontaneous dismutation of $\mathrm{O}_{2}{ }^{-}$into $\mathrm{H}_{2} \mathrm{O}_{2}$. As expected, eenzymatic conversion was only observed for the CATloaded $M G / L_{C A T} / P D A$ and $M G / L_{C A T} / P D A / P E G$ carriers. The $n M F I$ due to the resorufin product was $\sim 0 \%$ for both types of carriers, suggesting a total conversion of $\mathrm{H}_{2} \mathrm{O}_{2}$ into $\mathrm{H}_{2} \mathrm{O}$ and $\mathrm{O}_{2}$ by the encapsulated CAT (Figure 6a, pink lines). DIC images were also taken after $2 \mathrm{~h}$ of conversion which demonstrated the structural integrity and colloidal stability of the carriers (Figure 6a, inset).
We also assessed the potential of the CAT-loaded carriers to to conduct successive cycles of catalytic conversion. It is $8 \mathrm{f}$ high a microreactor to be able to perform in a sustained manner, but it is also worth taking into account that enzymes such as CAT are costly and challenging to obtain in a highly purified form suitable for human
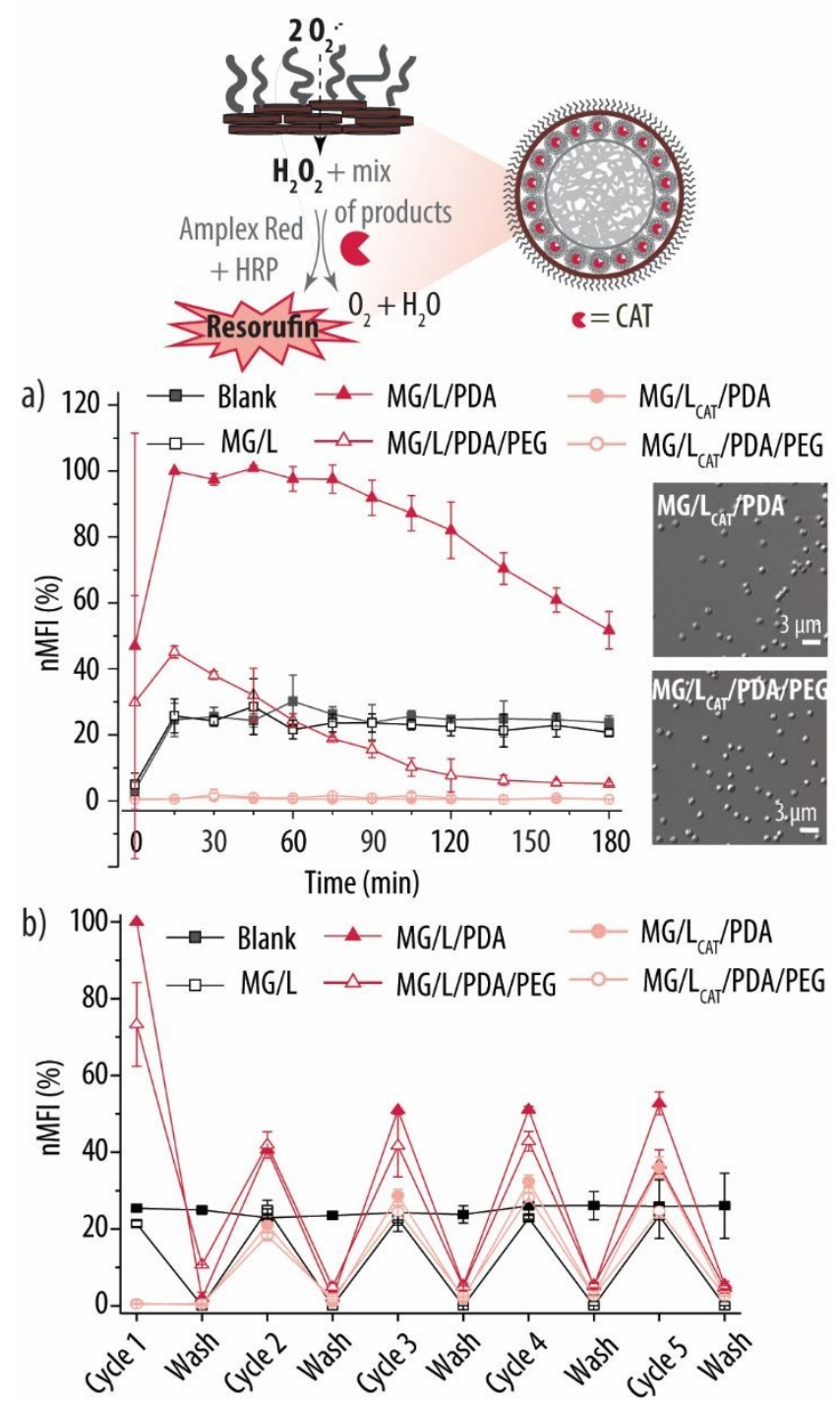

Figure 6. Non-enzymatic and enzymatic antioxidant activity of the dual-component carrier. The superoxide radical $\left(\mathrm{O}_{2}{ }^{-}\right)$interacts with the polydopamine (PDA) coating of the carrier to be converted into hydrogen peroxide $\left(\mathrm{H}_{2} \mathrm{O}_{2}\right)$. Next, $\mathrm{H}_{2} \mathrm{O}_{2}$ interacts with the catalase (CAT) enzyme encapsulated within the liposomal compartments to be converted into non-toxic $\mathrm{H}_{2} \mathrm{O}$ and $\mathrm{O}_{2} . \mathrm{H}_{2} \mathrm{O}_{2}$ acts as a co-substrate for the conversion of Amplex Red by the enzyme horseradish peroxidase (HRP) into the fluorescent resorufin. a) Kinetics of the catalytic conversion by uncoated $M G / L_{C A T} / P D A$ and PEGylated MG/L $\mathrm{L}_{C A T} / \mathrm{PDA} / \mathrm{PEG}$ carriers over time. As controls, empty MG/L/PDA and $\mathrm{MG} / \mathrm{L} / \mathrm{PDA} / \mathrm{PEG}$ carriers and $\mathrm{MG} / \mathrm{L}$ carriers without the PDA coating were considered. The blank denotes the reaction mixture only. b) Catalytic conversion of $\mathrm{O}_{2}{ }^{-}$for the different carriers for five subsequent cycles.

use. We conducted both reactions for several cycles by exchanging the resorufin product by a solution of fresh $\mathrm{O}_{2}{ }^{*}$ - over multiple rounds. The results were normalized to the MFI reading measured after the first reaction cycle at $37{ }^{\circ} \mathrm{C}$. As expected, the highest enzymatic conversion was achieved for the first cycle. The empty MG/L/PDA 


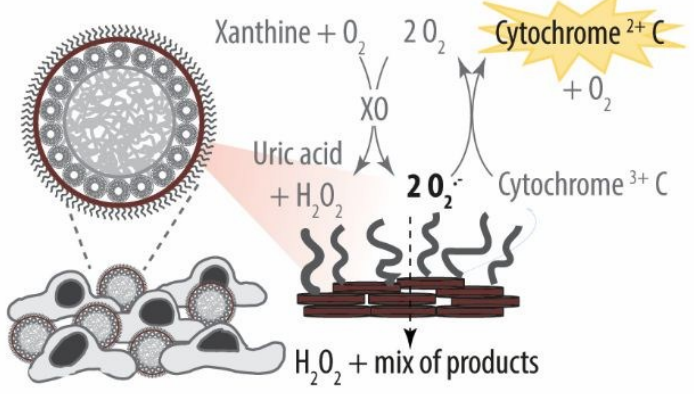

a)

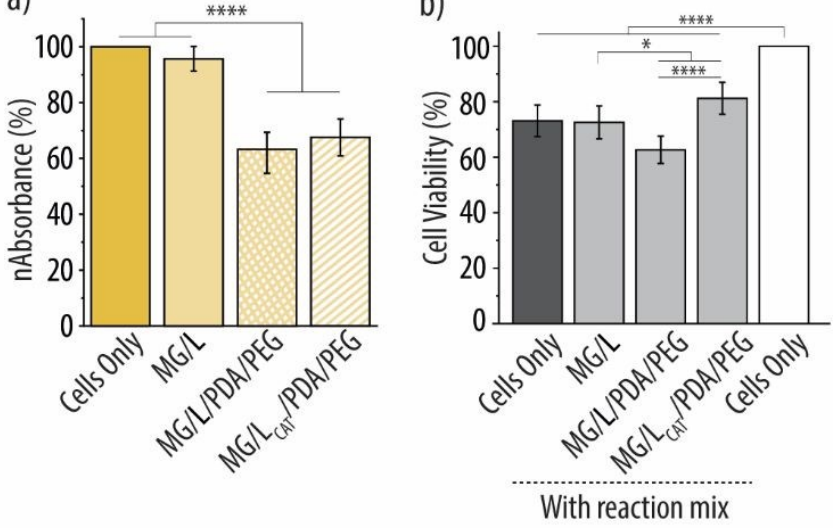

Figure 7. a) Antioxidant activity towards the superoxide radical $\left(\mathrm{O}_{2}{ }^{--}\right)$of empty and catalase (CAT)-loaded carriers in the presence of cells due to the poly(dopamine) (PDA) coating. As controls, carriers without the PDA coating MG/L and cells only are considered. The detection method is based on the oxygen $\left(\mathrm{O}_{2}\right)$ conversion into $\mathrm{O}_{2}{ }^{*}$ - by the xanthine/ xanthine oxidase (XO) system. $\mathrm{O}_{2}{ }^{-}$, in turn, oxidises the cytochrome ${ }^{3+} \mathrm{C}$ substrate into cytochrome ${ }^{2+} \mathrm{C}$ which can be detected spectrophotometrically at 550 $\mathrm{nm}$. As a result of the antioxidant PDA-coating, $\mathrm{O}_{2}{ }^{-}$is consumed, thus diminishing the amount of oxidized cytochrome ${ }^{2+}$ C. b) Cell viability readings after the catalytic conversion.

and MG/L/PDA/PEG carriers produced the highest level of nMFI of $\sim 100 \%$ and $\sim 75 \%$ for MG/L/PDA and MG/L/PDA/PEG, respectively (Figure $6 \mathrm{~b}$, red lines). Both types of carriers suffered a loss in activity for the second cycle since a nMFI of $\sim 40 \%$ was recorded for both MG/L/PDA and MG/L/PDA/PEG. Importantly, no further loss of activity could be detected for the subsequent cycles. The CAT loaded $\mathrm{MG} / \mathrm{L}_{\mathrm{CAT}} / \mathrm{PDA}$ and $\mathrm{MG} / \mathrm{L}_{\mathrm{CAT}} / \mathrm{PDA} / \mathrm{PEG}$ gave the lowest $\mathrm{nMFI}$ signal for the first catalytic round ( $0 \%$ for both carriers) (Figure $6 \mathrm{~b}$, pink lines). However, catalytic activity was lost for the second cycle since a nMFI increase up to $\sim 20 \%$ for both types of carriers was detected. However, following rounds of catalytic conversion resulted in no further decrease in activity for neither MG/L/PDA and MG/L/PDA/PEG since a similar value of nMFI was observed for the two types of carriers. These results again demonstrate the robustness of the reported system.

\subsection{Antioxidant activity in the presence of cells.}

Since our envisioned application involves ROS depletion in the body, assessing the microreactors activity in the presence of cells is a central aspect to address. In general, very few published reports have taken into consideration the biological milieu when conducting encapsulated biocatalysis, mainly focusing in intracellular activity.

3.4.1. Non-enzymatic antioxidant activity. As a first step to assess the potential of the as-prepared microreactors for ROS removal within the body, we evaluated the ability of the carriers to deplete $\mathrm{O}_{2}{ }^{--}$in the presence of cells. We incubated the RAW 264.7 cells with PEGylated CAT-loaded MG/L $\mathrm{L}_{\mathrm{CAT}} / \mathrm{PDA} / \mathrm{PEG}$ and empty
MG/L/PDA/PEG carriers in a solution containing cyitochrome lice xanthine and $\mathrm{XO}$ for $2 \mathrm{~h}$. The absorbance readifigs lue to the reduced cytochrome $\mathrm{C}$ are shown in Figure 7a. As controls, carriers without the PDA coating (MG/L) and cells only were considered. The results, which were normalized to the absorbance of cells only, show a significant decrease of $35 \%$ in nAbsorbance for cells incubated with carriers with the PDA coating (i.e., MG/L/PDA/PEG and $\mathrm{MG} / \mathrm{L}_{\mathrm{CAT}} / \mathrm{PDA} / \mathrm{PEG}$ ). As expected, carriers without PDA coating, did not produce a decrease in nAbsorbance. Also, no significant differences in nAbsorbance were observed for CAT-loaded or empty carriers. Importantly, Figure 7b shows no significant decrease in cell viability following biocatalytic conversion.

3.4.2. Combined antioxidant activity. Next, we aimed to demonstrate that the CAT-loaded microreactors can also impose a beneficial effect to the neighbouring cells as a result of ROS depletion. We anticipated that both the PDA coating and the CAT encapsulated within the subcompartments of the carrier would

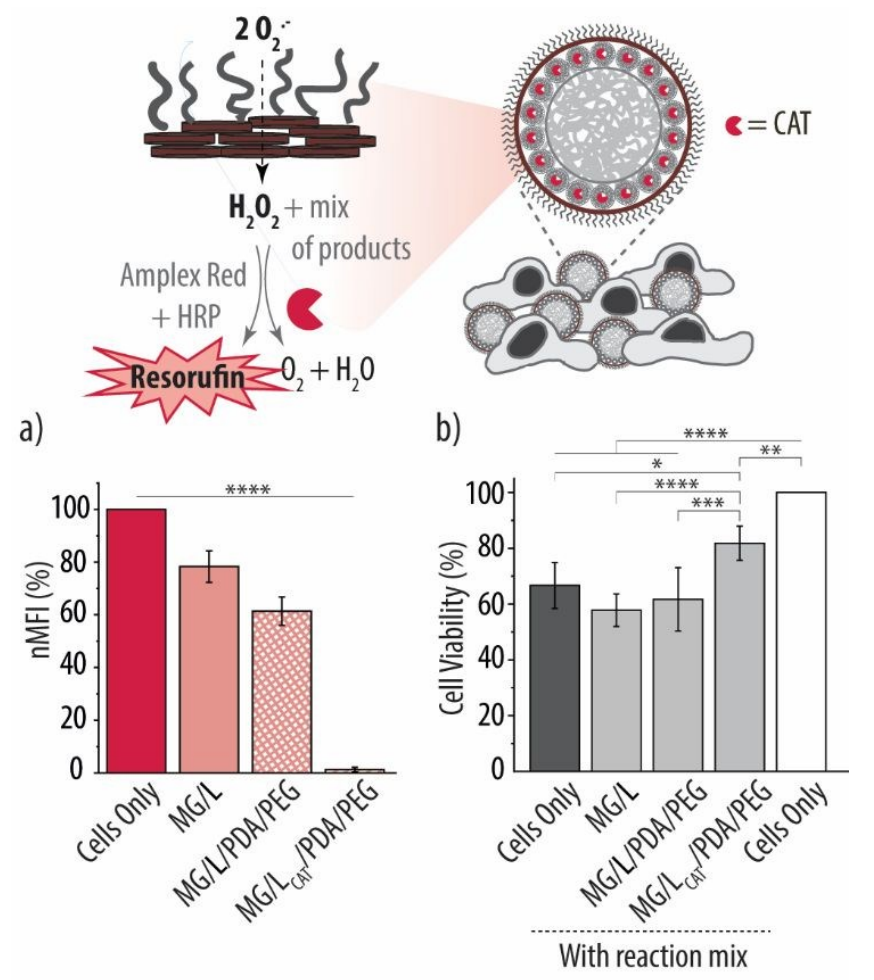

Figure 8. Non-enzymatic and enzymatic antioxidant activity of the dual-component carrier in the presence of cells. a) The superoxide radical $\left(\mathrm{O}_{2}{ }^{*}\right)$ interacts with the polydopamine (PDA) coating of the carrier to be converted into hydrogen peroxide $\left(\mathrm{H}_{2} \mathrm{O}_{2}\right)$. Next, $\mathrm{H}_{2} \mathrm{O}_{2}$ interacts with the catalase (CAT) enzyme to be converted into nontoxic $\mathrm{H}_{2} \mathrm{O}$ and $\mathrm{O}_{2}$. $\mathrm{H}_{2} \mathrm{O}_{2}$ acts as a co-substrate for the conversion of Amplex Red by the enzyme horseradish peroxidase (HRP) into fluorescent resorufin. b) Cell viability readings after the catalytic conversion.

remove/reduce both the toxic $\mathrm{O}_{2}{ }^{--}$and $\mathrm{H}_{2} \mathrm{O}_{2}$ in the presence of cells. By doing so, they would impose a beneficial effect to the seeded cells thus translating into a cell viability increase.

Thus, we assessed the ability of the carriers to conduct the catalysed cascade reaction by monitoring the resorufin fluorescent product. The carriers, by means of the PDA coating, will catalyse the dismutation of $\mathrm{O}_{2}{ }^{-}$into $\mathrm{O}_{2}$ and $\mathrm{H}_{2} \mathrm{O}_{2}$. Next, the CAT entrapped within $\mathrm{L}_{\text {CAT, }}$, will convert the toxic $\mathrm{H}_{2} \mathrm{O}_{2}$ into $\mathrm{H}_{2} \mathrm{O}$ and $\mathrm{O}_{2}$. The depletion of 
$\mathrm{H}_{2} \mathrm{O}_{2}$ will be monitored by the $\mathrm{HRP} /$ Amplex Red assay since $\mathrm{H}_{2} \mathrm{O}_{2}$ acts as a co-substrate for the conversion of Amplex Red into fluorescent resorufin by HRP. The results, which have been normalized to the MFI of cells without carriers, are shown in Figure 8a. The uncoated MG/L and the PEGylated empty MG/L/PDA/PEG carriers caused a decrease in $\mathrm{nMFI}$ of $\sim 20 \%$ and $\sim 40 \%$, respectively. In contrast, a drastic decrease of $\sim 100 \%$ in nMFI was observed upon incubation with the CAT-loaded MG/L $\mathrm{L}_{\mathrm{CAT}} / \mathrm{PDA} / \mathrm{PEG}$ carriers, thus demonstrating the catalytic activity of the encapsulated CAT. Furthermore, cell viability assays following the enzymatic cascade reaction, show a significant increase in cell viability ( 15\%) upon incubation with the CAT-loaded $\mathrm{MG} / \mathrm{L}_{\mathrm{CAT}} / \mathrm{PDA} / \mathrm{PEG}$ carriers (Figure $8 \mathrm{~b}$ ). Although in recent years some examples of microreactors conducting enzymatic reactions have translated into a beneficial effect to neighboring cells, this is the first example of a two-step catalytic conversion considering both non-enzymatic and enzymatic systems.

\section{Conclusions}

We have evaluated the potential of a recently developed dualcomponent carrier as a microreactor for ROS depletion. We employed a poly( $N$-isopropylacrylamide-co-acrylic acid) microgel core decorated with liposomes and subsequently coated with a protective poly(dopamine) shell (PDA) further functionalised by poly(ethylene glycol) (PEG). Such a combination affords the advantages of the two intrinsically different building blocks (i.e., microgels and liposomes) while minimizing some of their drawbacks.

We demonstrate the ability of the PEG coating against protein adsorption by evaluating different PEG grafting ratios. Furthermore, diminished cellular uptake was observed for the PEG coatings at the different grafting ratios for two relevant cell lines, namely, RAW 264.7 macrophages and HUVEC endothelial cells.

By combining the intrinsic antioxidant properties of PDA with the encapsulation of the antioxidant catalase enzyme, we demonstrate the potential of the carrier in depleting ROS such as the superoxide radical and hydrogen peroxide. The catalytic activity is also demonstrated in the presence of RAW 264.7 macrophages.

\section{Conflicts of interest}

There are no conflicts to declare.

\section{Acknowledgements}

This work was supported by the Lundbeck Foundation (grant agreement: R163-2013-15402).

\section{References}

1

K. Brieger, S. Schiavone, J. Miller and K. Krause, Swiss Med. Wkly., 2012, 142, w13659.

2 B. C. Dickinson and C. J. Chang, Nat. Chem. Biol., 2011, 7, 504-511.
C. Nathan and A. Cunningham-Bussel, Nat. Revelmmpungltine 2013, 13, 349-361.

DOI: 10.1039/C9BM00913B

K. J. Barnham, C. L. Masters and A. I. Bush, Nat. Rev. Drug Discovery, 2004, 3, 205-214.

N. S. Dhalla, R. M. Temsah and T. Netticadan, J. Hypertens., 2000, 18, 655-73.

Y. Wang and S. W. Walsh, J. Soc. Gynecol. Investig., 1996, 3, 179-84.

E. Hood, E. Simone, P. Wattamwar, T. Dziubla and V. Muzykantov, Nanomedicine, 2011, 6, 1257-1272. V. R. Muzykantov, J. Control. Release, 2001, 71, 1-21. X. Yi, M. C. Zimmerman, R. Yang, J. Tong, S. Vinogradov and A. V. Kabanov, Free Radic. Biol. Med., 2010, 49, 548-558. M. Eugénia, M. Cruz, M. Manuela Gaspar, M. Bárbara, F. Martins and M. Luísa Corvo, Methods Enzymol., 2005, 391, 395-413.

L. M. P. E. van Oppen, L. K. E. A. Abdelmohsen, S. E. van Emst-de Vries, P. L. W. Welzen, D. A. Wilson, J. A. M. Smeitink, W. J. H. Koopman, R. Brock, P. H. G. M. Willems, D. S. Williams and J. C. M. van Hest, ACS Cent. Sci., 2018, 4, 917-928.

A. Larrañaga, I. L. M. Isa, V. Patil, S. Thamboo, M. Lomora, M. A. Fernández-Yague, J.-R. Sarasua, C. G. Palivan and A. Pandit, Acta Biomater., 2018, 67, 21-31.

Y.-H. Lin, Y.-P. Chen, T.-P. Liu, F.-C. Chien, C.-M. Chou, C.-T. Chen and C.-Y. Mou, ACS Appl. Mater. Interfaces, 2016, 8, 17944-17954.

M. J. York-Duran, M. Godoy-Gallardo, C. Labay, A. J. Urquhart, T. L. Andresen and L. Hosta-Rigau, Colloids Surf., B, 2017, 152, 199-213.

M. Godoy-Gallardo, M. J. York-Duran and L. Hosta-Rigau, Adv. Healthcare Mater., 2018, 7, 1700917.

F. Itel, P. S. Schattling and Y. Zhang, Adv. Drug Delivery Rev., 2017, 118, 94-108.

K. Göpfrich, I. Platzman and J. P. Spatz, Trends Biotechnol., 2018, 36, 938-951.

R. Chandrawati, S.-F. Chong, A. N. Zelikin, L. Hosta-Rigau, B. Städler and F. Caruso, Soft Matter, 2011, 7, 9638.

L. Hosta-Rigau, P. Schattling, B. M. Teo, M. E. Lynge and B. Städler, J. Mater. Chem. B, 2014, 2, 6686-6691.

Y. Zhang, P. S. Schattling, F. Itel and B. Städler, ACS omega, 2017, 2, 7085-7095.

Y. Zhang, M. Baekgaard-Laursen and B. Städler, Adv. Healthcare Mater., 2017, 6, 1601141.

B. Thingholm, P. Schattling, Y. Zhang and B. Städler, Small, 2016, 12, 1806-1814.

M. Godoy-Gallardo, C. Labay, V. D. V.D. Trikalitis, P. J. P. J. Kempen, J. B. J. B. Larsen, T. L. Andresen and L. HostaRigau, ACS Appl. Mater. Interfaces, 2017, 9, 15907-15921. M. Godoy-Gallardo, C. Labay, M. M. T. Jansman, P. K. Ek and L. Hosta-Rigau, Adv. Healthcare Mater., 2017, 6, 1601190.

F. Itel, J. Skovhus Thomsen and B. Städler, ACS Appl. Mater. Interfaces, 2018, 10, 30180-30190.

L. Hosta-Rigau, M. J. York-Duran, T. S. Kang and B. Städler, Adv. Funct. Mater., 2015, 25, 3860-3869.

M. Godoy-Gallardo, C. Labay and L. Hosta-Rigau, ACS Appl. 
Mater. Interfaces, 2019, 11, 5862-5876.

28 M. J. York-Duran, P. K. Ek, M. Godoy-Gallardo and L. Hosta-

Rigau, Colloids Surf., B, 2018, 171, 427-436.

29 B. M. B. M. Teo, R. Van Der Westen, L. Hosta-Rigau and B. Städler, Biochim. Biophys. Acta, Gen. Subj., 2013, 1830, 4838-4847.

30 Y. Liu, K. Ai, X. Ji, D. Askhatova, R. Du, L. Lu and J. Shi, J. Am. Chem. Soc., 2017, 139, 856-862.

31 D. Bhowmick, S. Srivastava, P. D'Silva and G. Mugesh, Angew. Chemie Int. Ed., 2015, 54, 8449-8453.

32 L. Hosta-Rigau and B. Stadler, Mol Pharm, 2013, 10, 27072712.

33 N. D. Spencer, J. A. Hubbell, R. Michel, R. Hofer, D. L. Elbert, N.-P. Huang, J. Voros, A. Rossi and M. Textor, Langmuir, 2002, 17, 489-498.

34 F.-P. Chang, Y.-P. Chen and C.-Y. Mou, Small, 2014, 10, 4785-4795.

35 S. A. Jadhav, V. Brunella, I. Miletto, G. Berlier and D. Scalarone, J. Appl. Polym. Sci., , DOI:10.1002/app.44181.

36 Y. Katsumoto, T. Tanaka, H. Sato and Y. Ozaki, J. Phys. Chem. A, 2002, 106, 3429-3435.

37 A. Blume, Curr. Opin. Colloid Interface Sci., 1996, 1, 64-77.

38 L. Hosta-Rigau, M. J. York-Duran, Y. Zhang, K. N. Goldie and B. Städler, ACS Appl. Mater. Interfaces, 2014, 6, 1277112779.

39 J. S. Suk, Q. Xu, N. Kim, J. Hanes and L. M. Ensign, Adv. Drug Delivery Rev., 2016, 99, 28-51.

40 R. Batul, T. Tamanna, A. Khaliq and A. Yu, Biomater. Sci., 2017, 5, 1204-1229.

41 S. Pasche, S. M. De Paul, J. Vörös, N. D. Spencer and M. Textor, Langmuir, 2003, 19, 9216-9225.

42 U. Wattendorf, M. C. Koch, E. Walter, J. Vörös, M. Textor and H. P. Merkle, Biointerphases, 2006, 1, 123-133.

43 N. Bertrand and J. C. Leroux, J. Control. Release, 2012, 161, 152-163.

44 E. Niki and N. Noguchi, Acc. Chem. Res., 2004, 37, 45-51.

45 K.-Y. Ju, Y. Lee, S. Lee, S. B. Park and J.-K. Lee, Biomacromolecules, 2011, 12, 625-632.

46 Y. Liu, K. Ai and L. Lu, Chem. Rev., 2014, 114, 5057-5115.

47 C. Zhu, F. Itel, R. Chandrawati, X. Han and B. Städler, Biomacromolecules, 2018, 19, 4379-4385. 